\title{
Compensation for Breach of the General Data Protection Regulation
}

\author{
Eoin O’Dell ${ }^{*}$
}

\begin{abstract}
Article 82(1) of the General Data Protection Regulation (GDPR) provides that any 'person who has suffered material or non-material damage as a result of an infringement of this Regulation shall have the right to receive compensation from the controller or processor for the damage suffered'. As a consequence, compliance with the GDPR is ensured through a mutually reinforcing combination of public and private enforcement that blends public fines with private damages.
\end{abstract}

After the introduction, the second part of this article compares and contrasts Article 82(1) GDPR with compensation provisions in other EU Regulations and Directives and with the case law of the CJEU on those provisions, and compares and contrasts the English version of Article 82(1) GDPR with the versions of that Article in the other official languages of the EU, and concludes that at least five of the versions of Article 82(1) GDPR are unnecessarily ambiguous, though the CJEU (eventually, if and when it is asked) is likely to afford it a consistent broad interpretation. However, the safest course of action at this stage is to provide expressly for a claim for compensation in national law. The third part of this article compares and contrasts the compensation provisions in the Irish government's General Scheme of the Data Protection Bill 2017 with existing legislation and case law in Ireland and the UK, and with incorporating legislation and Bills in other EU Member States, and concludes that the Heads of the Scheme do not give full effect to Article 82(1) GDPR. Amendments to the Scheme are therefore proposed.

To ensure that any person who has suffered such damage has an effective remedy pursuant to Article 47 CFR, Member States will have to provide, pursuant to Article 19 TEU, remedies sufficient to ensure effective legal protection in the fields of privacy and data protection. In particular, they will have to provide expressly for a claim for compensation, incorporating Article 82(1) GDPR into national law. Claims for compensation are an important part of the enforcement architecture of the GDPR. Private enforcement will help to discourage infringements of the rights of data subjects; it will make a significant contribution to the protection of privacy and data protection rights in the European Union; and it will help to ensure that the great promise of the GDPR is fully realised.

\footnotetext{
${ }^{*}$ Fellow and Associate Professor, School of Law, Trinity College Dublin. Earlier drafts of this paper were presented at the Irish Centre for European Law's Privacy and Data Protection Conference in Dublin on 9 May 2017 and at the FP Logue GDPR Workshop in Dublin on 28 July 2017.

I would like to thank Katy Barnett, Mark Bell, William Binchy, Karen Burke-Logue, Darina Byrne, Seamus Carroll, Helen Dixon, Sara Drake, Catherine Donnelly, Gary Fitzgerald, Rosemary Jay, Deirdre Kilroy, Mindaugas Kiškis, Ewa Komorek, Ronan Lupton, Orla Lynskey, Caoimhín MacMaoláin, Simon McGarr, Paul Nemitz, Diarmuid Rossa Phelan, Carlo Piltz, Aurélie Pols, Linda Scales, and Alex Schuster, for their suggestions and advice. I would also like to thank Patrícia Macedo Alves, Nadia Arnaboldi, Edward Arnold, Jürgen Barkhoff, Lorna Barton, Ralf Bendrath, Natalija Bitiukova, Paul Breitbarth, Anna Buchta, Siobhán Coen, Ashley Cohen, Emerald de Leeuw, Sylvia de Mars, Evita Dionysiou, Sara Domingo, Carlos Friacas, Atis Gailis, lan Gauci, Joost Gerritsen, Edina Harbinja, Ásta Helgadóttir, Johanna Hjalmarsson, Nils Hoppe, Jaakko Husa, Markus Kastelitz, Anton Toni Klančnik, Damian Klimas, Paddy Leerssen, Hans Peter Lehofer, Corinna Salvadori Lonergan, Gillian Martin, Tomáš Masný, Irene Maxwell, Selga Medenieks, Tanya Möller, Raluca Nechimis, Sarah Pasetto, Richard Pruim, Ollivier Robert, Alexandra Qu, Chiara Rustici, Jan Sandtr $\varnothing$, Christoph Schmon, Thomas Schweiger, Natacha Soto, Sophie Stalla-Bourdillon, Guilherme Svizzero, Ivona Vidovic, Gabriela Zanfir, and Google Translate, for their help with translations, national incorporations, and related issues.
}

All links in these notes were last visited on 30 September 2017. The usual disclaimers apply. 


\section{INTRODUCTION}

\subsection{Protecting Privacy}

At the beginning of the famous balcony scene in Shakespeare's Romeo and Juliet, Romeo overhears Juliet longing for him. He startles her, and she berates him for hiding in darkness and listening to her private thoughts:

What man art thou that, thus bescreened in night, So stumblest on my counsel? ${ }^{1}$

Of course, when she learns that it is Romeo who has startled her, she relents. They talk, and curse their fates that their families bear an ancient grudge, and ultimately pledge their love for one another. But her annoyance at being overheard when she thought she was alone and was giving voice to her most intimate feelings reflects our deepest intuitions about the importance of privacy. The law accordingly provides a broad range of protections for a wide variety of privacy values, interests, and rights. ${ }^{2}$ Thus, for example, in the European Union, the Charter of Fundamental Rights guarantees the right to respect for private life, in general, and to the protection of personal data, in particular. ${ }^{3}$ The Court of Justice of the European Union has long stressed the importance of these rights ${ }^{4}$; the Charter has elevated their recognition and protection; ${ }^{5}$ and they are now crucial to the EU legal order. ${ }^{6}$ These high-level

\footnotetext{
${ }^{1}$ William Shakespeare, Romeo and Juliet, Act II, Scene 2, lines 52-53; René Weiss (ed), Romeo and Juliet (Arden Shakespeare, Third Series; Bloomsbury 2012) 190.

2 See, eg, Eoin Carolan and Hilary Delany, The Right to Privacy (Round Hall 2008) ch 1; Ronald Krotoszynski, Privacy Revisited: A Global Perspective on the Right to Be Left Alone (Oxford University Press 2016) ch 1; Denis Kelleher, Privacy and Data Protection Law in Ireland (2nd ed, Bloomsbury, Dublin, 2015) [hereafter: Kelleher] ch 1.

${ }^{3}$ See Articles 7 and 8 of the Charter of Fundamental Rights of the European Union (2012 OJ C 326/2) [hereafter CFR]; see also Article 16(1) of the Treaty on the Functioning of the European Union (2012 OJ C 326) [hereafter TFEU] and Article 39 of the Treaty on the European Union (2012 OJ C 326) (the full text of these Articles is set out in $\S \S 1-3$ of Appendix I).

See, generally, Herke Kranenborg, 'Article 8 - Protection of Personal Data' in Steve Peers, Tamara Hervey, Jeff Kenner, and Angela Ward (eds), The EU Charter of Fundamental Rights - A Commentary (Hart Publishing 2014) [hereafter Peers et al] 223; Hielke Hijmans, The European Union as Guardian of Internet Privacy: The Story of Art 16 TFEU (Springer-Verlag GmbH 2016) [hereafter Hijmans]; Kelleher, ch 4.

4 Joined Cases C-465/00, C-138/01 and C-139/01 Rechnungshof v Österreichischer Rundfunk (ECLI:EU:C:2003:294; ECJ, 20 May 2003) [68], [73]-[75]; Case C-275/06 Productores de Música de España (Promusicae) v Telefónica de España [2008] ECR I-271 (ECLI:EU:C:2008:54; ECJ, 29 January 2008) [63].

${ }^{5}$ Joined Cases C-92/09 and C-93/09 Volker und Markus Schecke GbR and Hartmut Eifert $v$ Land Hessen (EU:C:2010:662; CJEU, 9 November 2010) [47]; Joined Cases C-293/12 and C-594/12 Digital Rights Ireland Ltd v Minister for Communications, Marine and Natural Resources (ECLI:EU:C:2014:238; CJEU, 8 April 2014) [29], [40]; Case C-131/12 Google Spain SL and Google Inc v Agencia Española de Protección de Datos (ECLI:EU:C:2014:317; CJEU, 13 May 2014) [69]; C-212/13 Ryneš v Úřad pro ochranu osobních údajů (ECLI:EU:C:2014:2428; CJEU, 11 December 2014) [28]-[29]; Case C-230/14 Weltimmo sro v Nemzeti Adatvédelmi és Információszabadság Hatóság (ECLI:EU:C:2015:639; CJEU, 01 October 2015) [25], [30]; Case C-362/14 Schrems v Data Protection Commissioner (ECLI:EU:C:2015:650; CJEU, 6 October 2015) [37]-[40]; Joined Cases C-203/15 Tele2 Sverige AB v Post- och telestyrelsen and C-698/15 Secretary of State for the Home Department $v$ Watson (ECLI:EU:C:2016:970; CJEU, 21 December 2016) [93]; Opinion 1/15 (ECLI:EU:C:2017:592; CJEU, 26 July 2017) on the EU-Canada Data Sharing Agreement [121]-[126], [136], [140]-[141].
} 
rights are given detailed effect by the General Data Protection Regulation. ${ }^{7}$ Rights require remedies. Consequently, the GDPR provides a strong regime of regulation and sanctions. Public regulation and enforcement are undertaken by national data protection supervisory authorities ${ }^{8}$ with the power to impose administrative fines, ${ }^{9}$ and by a centralised European Data Protection Board. ${ }^{10}$ However, private enforcement is a significant part of the 'Copernican Revolution'11 worked by the GDPR. Hence, reflecting the right to an effective judicial remedy in accordance with Article $47 \mathrm{CFR},{ }^{12}$ data subjects can, pursuant to Article 82 GDPR, claim compensation from controllers or processors for damage suffered from infringements of the GDPR.

\section{As a consequence, compliance with the GDPR is ensured through a mutually} reinforcing combination of public and private enforcement that blends public fines with private damages, ${ }^{13}$ much as public enforcement of EU competition law is complemented by private enforcement actions after Courage $v$ Crehan $^{14}$ and

\footnotetext{
${ }^{6}$ Orla Lynskey, 'Deconstructing Data Protection: The "Added-Value" of a Right to Data Protection in the EU Legal Order' (2014) 63(3) International and Comparative Law Quarterly 569; Gloria González Fuster, The Emergence of Personal Data Protection as a Fundamental Right of the EU (Springer-Verlag GmbH 2014) chs 6 and 7; Maria Tzanou, The Fundamental Right to Data Protection: Normative Value in the Context of Counter-Terrorism Surveillance (Hart Publishing 2017) chs 1 and 2; Maja Brkan, 'The Court of Justice of the EU, Privacy and Data Protection: Judge-Made Law as a Leitmotif in Fundamental Rights Protection' in Maja Brkan and Evangelia Psychogiopoulou (eds), Courts, Privacy and Data Protection in the Digital Environment (Edward Elgar 2017) ch 2; contrast Bart Sloot, 'Legal Fundamentalism: Is Data Protection Really a Fundamental Right?' in Ronald Leenes, Rosamunde van Brakel, Serge Gutwirth and Paul de Hert (eds), Data Protection and Privacy: (In)visibilities and Infrastructures (Springer-Verlag GmbH 2017) ch 1.

${ }^{7}$ Regulation 2016/679 of the European Parliament and of the Council of 27 April 2016 on the protection of natural persons with regard to the processing of personal data and on the free movement of such data, and repealing Directive 95/46/EC (2016 OJ L 119) [the General Data Protection Regulation; hereafter GDPR]. It will apply from 25 May 2018 (see Article 99(2) GDPR). The provisions in $n 3$ provide the legal basis for the GDPR (see the first citation and Recital 1 GDPR, set out in $§ 4$ of Appendix I).

${ }^{8}$ Hijmans, ch 6; David Wright, 'Enforcing Privacy' in David Wright and Paul De Hert (eds), Enforcing Privacy: Regulatory, Legal and Technological Approaches (Springer-Verlag GmbH 2016) ch 2; Marek Szydło, 'The Independence of Data Protection Authorities in EU Law: Between the Safeguarding of Fundamental Rights and Ensuring the Integrity of the Internal Market' (2017) 41 European Law Review 369.

9 Article 83 GDPR; see Hazel Grant and Hannah Crowther, 'How Effective Are Fines in Enforcing Privacy?' in Wright and De Hert, ibid ch 13; Sebastian Golla, 'Is Data Protection Law Growing Teeth? The Current Lack of Sanctions in Data Protection Law and Administrative Fines under the GDPR' (2017) 8(1) Journal of Intellectual Property, Information Technology and E-Commerce Law 70; Paul Voigt and Axel von dem Bussche, The EU General Data Protection Regulation (GDPR): A Practical Guide (Springer-Verlag GmbH 2017) ch 7; Rosemary Jay, Guide to the General Data Protection Regulation (Thomson Reuters Sweet \& Maxwell 2017) [hereafter Jay] ch 18.

10 Orla Lynskey, 'The “Europeanisation" of Data Protection Law' (2017) 19 Cambridge Yearbook of European Legal Studies 1.

${ }^{11}$ Christopher Kuner, 'The European Commission's Proposed Data Protection Regulation: A Copernican Revolution in European Data Protection Law' (2012) Bloomberg BNA Privacy and Security Law Report 1.

${ }^{12}$ See, generally, Pekka Aalto, Herwig Hofmann, Liisa Holapinen, Elina Punio, Laurent Pech, Debbie Sayers, Dinah Shelton, and Angela Ward, 'Article 47 - Right to an Effective Remedy and to a Fair Trial' in Peers et al, 1197; see also ns 18, 34-40, 98-105, 120-22, and 153; the full text of Article 47 CFR is set out in $\S 3$ of Appendix I.

${ }^{13}$ On fines, see n 9; on damages, see Jay, ch 13; Emmanuela Truli, 'The General Data Protection Regulation and Civil Liability' in Mor Bakhoum, Beatriz Conde Gallego, Mark-Oliver Mackenrodt, and Gintarè Surblytè (eds), Personal Data in Competition, Consumer Protection and IP Law - Towards a Holistic Approach? (Springer-Verlag $\mathrm{GmbH} 2017$; forthcoming).

${ }^{14}$ Case C-453/99 Courage Ltd v Bernard Crehan [2001] ECR I-6297 (ECLI:EU:C:2001:465, ECJ, 20 September
} 2001); Rebecca Williams, 'European Competition Law - Beer Tie Cases - Restitution - In Pari Delicto Rule' (2001) 
Manfredi, ${ }^{15}$ and the Damages Directive. ${ }^{16}$ In particular, claims for compensation pursuant to Article 82 GDPR strengthen the working of the Regulation, since they discourage practices, frequently covert, which are liable to infringe the rights of data subjects, thereby making a significant contribution to the protection of privacy and data protection rights in the European Union. ${ }^{17}$

Consequently, Article 82(1) is a crucial part of the enforcement architecture of the GDPR. Unfortunately, there is an ambiguity at the heart of the English language version of that Article that calls its efficacy into question. It is an ambiguity that is shared by some, but not the majority, of the other language versions. Resolving that ambiguity is at the heart of this article. In particular, it recommends that an express provision for compensation be included in national legislation giving effect to the GDPR. To begin the process that leads to that recommendation, it is first necessary to put Article 82(1) in the context of related current EU compensation provisions, and then to describe the structure of the analysis and common themes in this article.

\subsection{Incorporation and Implementation}

Article 79 GDPR provides for a right to an effective judicial remedy against a controller or processor, and Article 82 provides for a claim to compensation as an important aspect of that effective judicial remedy. ${ }^{18}$ In particular, Article $82(1)$ GDPR provides:

23 Dublin University Law Journal (ns) 194; Albertina Albors-Llorens, 'Courage v Crehan: Judicial Activism or Consistent Approach?' (2002) 61 Cambridge Law Journal 38; Sara Drake, 'Scope of Courage and the Principle of Individual Liability for Damages: Further Development of the Principle of Effective Judicial Protection' (2006) 31(6) European Law Review 841. Walter van Gerven, 'Private Enforcement of EC Competition in the ECJ Courage $v$ Crehan and the Way Ahead' in Jürgen Basedow (ed), Private Enforcement of EC Competition Law (Kluwer Law International 2007) 28; Katri Havu, 'Horizontal Liability for Damages in EU Law - The Changing Relationship of EU and National Law' (2012) 18 European Law Journal 407.

${ }^{15}$ Joined Cases C-295/04 to C-298/04 Manfredi v Lloyd Adriatico Assicurazioni SpA [2006] ECR I-6619 (ECLI:EU:C:2006:461; ECJ, 13 July 2006).

${ }^{16}$ Directive 2014/104/EU of the European Parliament and of the Council of 26 November 2014 on certain rules governing actions for damages under national law for infringements of the competition law provisions of the Member States and of the European Union (2014 OJ L 349) [the Damages Directive]; implemented in Ireland by the European Union (Actions for Damages for Infringements of Competition Law) Regulations 2017 (SI No 43 of 2017); see, generally, Kai Hüschelrath and Heike Schweitzer (eds), Public and Private Enforcement of Competition Law in Europe: Legal and Economic Perspectives (Springer-Verlag GmbH 2014); Carlo Petrucci, 'Effective Private Enforcement of EU Competition Law: An Input and Output Legitimacy Analysis of Collective Redress' in Sara Drake and Melanie Smith (eds), New Directions in the Effective Enforcement of EU Law and Policy (Edward Elgar 2016) [hereafter Drake \& Smith] ch 9.

${ }^{17}$ See, by analogy, the approach of the CJEU to the private enforcement of EU competition rules: Courage $v$ Crehan (n 14) [27]; Manfredi ( $\mathrm{n}$ 15) [91]; Case C-360/09 Pfleiderer AG v Bundeskartellamt [2011] ECR I-5161 (ECLI:EU:C:2011:389, CJEU, 14 June 2011) [29]; Case C-199/11 Europese Gemeenschap v Otis NV (ECLI:EU:C:2012:2390; CJEU, 6 November 2012) [42]; Case C-536/11 Bundeswettbewerbsbehörde $v$ Donau Chemie AG (ECLI:EU:C:2013:366; CJEU, 6 June 2013) [23]; Case C-557/12 Kone AG v ÖBB-Infrastruktur AG (ECLI:EU:C:2014:1317; CJEU, 5 June 2014) [23].

${ }^{18}$ The full texts of Articles 79 and 82 GDPR are set out in $\S 4$ of Appendix I; on the right to an effective judicial remedy, see Article 47 CFR (ns 12, 34-40, 98-107, 120-22 and 153). 
Any person who has suffered material or non-material damage as a result of an infringement of this Regulation shall have the right to receive compensation from the controller or processor for the damage suffered.

Regulations have general application, are binding in their entirety, and are directly applicable in all EU countries ${ }^{19}$; so there is usually no need for Member States to take any further action. However, unusually for a Regulation, ${ }^{20}$ legislation is necessary to incorporate ${ }^{21}$ some elements of the GDPR into Irish law. The government has therefore published a draft General Scheme of a Data Protection Bill $2017^{22}$; and Head 91 of the Scheme provides 'a data protection action' to data subjects whose rights under the GDPR or its incorporating legislation are infringed. ${ }^{23}$

The Police and Criminal Justice Authorities Directive ${ }^{24}$ was adopted alongside the GDPR. It aims to protect personal data processed for law enforcement purposes and it, too, provides for both public and private enforcement, including the right to an effective judicial remedy in Article 54 and a claim to compensation in Article $56 .{ }^{25}$ In particular, Article 56 PCJAD provides:

Member States shall provide for any person who has suffered material or non-material damage as a result of an unlawful processing operation or of any act infringing national provisions adopted pursuant to this Directive to have the right to receive compensation for the damage suffered from the controller or any other authority competent under Member State law.

Whereas EU Regulations have general application, EU Directives are binding as to the results to be achieved but leave to national authorities the choice of form and methods to achieve those results. ${ }^{26}$ Hence, Article 56 PCJAD leaves the form of the claim for compensation to the national law of the Member States; national

\footnotetext{
${ }^{19}$ See Article 288 TFEU.

${ }^{20}$ This is unusual, but not unique; for another example, see $\mathrm{n} 46$.

${ }^{21}$ Recital 8 GDPR provides that Member States may 'incorporate elements of this Regulation into their national law' (emphasis added; the full text of Recital 8 GDPR is set out in $\S 4$ of Appendix I), so the process of giving further effect to the Regulation in national law is described in this article as one of incorporation, to distinguish it from the process of implementing (or transposing) a Directive. On the nature and limits of such incorporation, see $§ 2.6$.

${ }^{22}$ Hereafter: the Scheme. It was published by the Irish Government on 12 May 2017 <http://www.justice.ie/en/JELR/Pages/PR17000155>.

${ }^{23}$ The full text of Head 91 is set out in $\S 1$ of Appendix II; it is analysed in detail in Part 3.

${ }^{24}$ Directive (EU) 2016/680 of the European Parliament and of the Council of 27 April 2016 on the protection of natural persons with regard to the processing of personal data by competent authorities for the purposes of the prevention, investigation, detection or prosecution of criminal offences or the execution of criminal penalties, and on the free movement of such data, and repealing Council Framework Decision 2008/977/JHA (2016 OJ L 116) [The Police and Criminal Justice Authorities Directive; hereafter PCJAD]; this will have to be implemented before 6 May 2018 (see Article 63(1) PCJAD).

${ }^{25}$ The full texts of Articles 54 and 56 PCJAD are set out in $\S 5$ of Appendix I.

${ }^{26}$ See Article 288 TFEU; see Paul Craig, 'The Legal Effect of Directives: Policy, Rules and Exceptions' (2009) 34(3) European Law Review 349.
} 
legislation implementing the PCJAD will need to contain express provisions providing for compensation for breach of the Directive; and this, too, is provided for in the Scheme. In particular, Head 58 of the Scheme provides a claim for compensation to any person whose rights under the Part of the Scheme implementing the PCJAD have been infringed. ${ }^{27}$

Coming down the tracks after the GDPR and the PCJAD is the proposed ePrivacy Regulation. ${ }^{28}$ It aims to protect personal data in the electronic communications sector; and it, too, provides for both public and private enforcement, including the right to an effective judicial remedy in Article 21 (by reference to Article 79 GDPR) and a claim to compensation in Article $22 .{ }^{29}$ In particular, Article 22 pePR provides:

Any end-user of electronic communications services who has suffered material or non-material damage as a result of an infringement of this Regulation shall have the right to receive compensation from the infringer for the damage suffered, ...

The supervision and enforcement of the pePR, and remedies for its breach, are integrated with those provided by the GDPR. ${ }^{30}$ These are the kinds of matters provided for in the Scheme incorporating the GDPR. It is therefore very likely that some incorporating legislation will also be necessary for the pePR. ${ }^{31}$ Moreover, if the legislation incorporating the GDPR contains or should contain an express claim for compensation, then any legislation incorporating the pePR should also contain an express claim for compensation.

\subsection{The Structure of the Analysis}

Against this background of Article 82(1) GDPR, Article 22 pePR and Article 56 PCJAD, Part 2 of this article therefore compares and contrasts them with compensation provisions in other EU Regulations and Directives and with the case law of the CJEU on those provisions, and compares and contrasts the English language version of Article 82(1) GDPR with the versions of that Article in the other official languages of the EU, at least five of which are unnecessarily ambiguous. It concludes that, although the CJEU (eventually, if and when it is asked) is likely to afford Article 82(1)

\footnotetext{
${ }^{27}$ The full text of Head 58 is set out in $\S 1$ of Appendix II.

${ }^{28}$ Proposal 2017/0003 of 10 January 2017 for a Regulation of the European Parliament and of the Council concerning the respect for private life and the protection of personal data in electronic communications and repealing Directive 2002/58/EC (COM(2017) 10 final - 2017/03 (COD)) [the proposed ePrivacy Regulation; hereafter pePR (my acronym)]; see also $n 123$.

${ }^{29}$ The full texts of the Commission's proposals for Articles 21 and 22 pePR are set out in $\S 6$ of Appendix I.

${ }^{30}$ See especially Articles 18-24 pePR.

${ }^{31}$ However, there is no equivalent pePR recital to Recital 8 GDPR (see $n$ 21), which may signal that the EU Commission does not perceive a need for incorporating legislation.
} 
a consistent broad interpretation, the best solution is for Article 82(1) GDPR and Article 22 pePR to be expressly incorporated into national law, just

Article 56 PCJAD has to be implemented in national law. Hence, the Scheme incorporating the GDPR and implementing the PCJAD should make express provision for claims for compensation, as should any future legislation incorporating the pePR.

Part 3 of this article therefore examines the Scheme's compensation provisions, and compares and contrasts them with existing legislation, with case law in Ireland the and UK, and with incorporating legislation and Bills in other EU Member States. It concludes that Head 58 is an incomplete implementation of Articles 54 and 56 PCJAD, and that Head 91 is an incomplete incorporation of Articles 79 and 82 GDPR. Consequently, it argues for alternative drafts of those Heads (and of a possible equivalent legislative provision to incorporate Articles 21 and 22 pePR), the full text of which is set out in Appendix II. ${ }^{32}$ In particular, it argues for a common framework for all three Heads, constructed in each case upon an express claim for compensation that tracks as much as possible the language of the relevant Regulation or Directive. Coherence between these three claims will ensure consistent enforcement and meaningful vindication of plaintiffs' rights pursuant to the GDPR, the PCJAD, and the pePR. The conclusion in Part 4 draws these various strands together.

\subsection{Recurring Themes: Private Enforcement and Effective Remedies}

Two themes recur throughout the analysis. The first is the importance of private enforcement of the GDPR. In particular, some of the choices in the Irish Scheme have the effect of limiting public enforcement, ${ }^{33}$ and private enforcement mechanisms therefore become crucial.

The second theme is the right to pursue legal remedies in order to vindicate privacy and data protection rights, which the CJEU emphasised in Schrems ${ }^{34}$ is of the essence of the fundamental right to an effective judicial remedy enshrined in Article 47 CFR. This right is expressly secured, in general terms, in Article 79 GDPR, Article 54 PCJAD,

\footnotetext{
${ }^{32}$ Appendix II is in four sections. $\$ 1$ sets out the full text of the existing drafts of Heads 58 and 91 . $§ 2$ tracks amendments to Heads 58 and 91 proposed in this article. $\S 3$ shows what Heads 58 and 91 would look like after those amendments. §4 provides the full text of a draft Head to incorporate Articles 21 and 22 pePR, modelled on the versions of Heads 58 and 91 in Part 3.

${ }^{33}$ For example, Head 23 of the Scheme envisages that administrative fines may not be imposed on public authorities and bodies for breaches of the GDPR and its incorporating legislation arising in the course of the provision of their public functions.

${ }^{34}$ See Case C-362/14 Schrems v Data Protection Commissioner (ECLI:EU:C:2015:650; CJEU, 6 October 2015) [95]; compare Case C-131/15 Club Hotel Loutraki v Commission (ECLI:EU:C:2016:989; CJEU, 21 December 2016) [49]; Case C-72/15 R (on the application of PJSC Rosneft Oil Company) v Her Majesty's Treasury (ECLI:EU:C:2017:236; CJEU, 28 March 2017) [73]; and see also ns 12, 18, 98-105, 120-22, and 153.
} 
and Article 21 pePR $^{35}$ and, in particular, in the compensation claims in Article 82 GDPR, Article 56 PCJAD and Article 22 pePR. In any action brought by a plaintiff seeking a remedy for infringement of privacy and data protection rights, Article 47 CFR is likely to be relied upon by any court - and, especially, by the CJEU - to ensure that those Articles and any legislative provisions incorporating or implementing them ${ }^{36}$ are, indeed, effective.

The right to an effective remedy in Article 47 CFR is reinforced by the corresponding obligation upon the State, enshrined in Article $19 \mathrm{TEU},{ }^{37}$ to 'provide remedies sufficient to ensure effective legal protection in the fields covered by Union law'. ${ }^{38}$ The fields covered by EU law include the rights to privacy and data protection, ${ }^{39}$ given effect in this context by the GDPR, the PCJAD, and the pePR. This obligation is likely to be relied upon by any court - and, especially, by the CJEU - to reinforce the Article 47 rights of a plaintiff seeking a remedy for infringement either of those various EU instruments or, in particular, of national legislative provisions incorporating or implementing them. ${ }^{40}$

Article 47 CFR and Article 19 TEU therefore lend crucial support to the private enforcement of privacy and data protection rights, and in particular to the claims for

\footnotetext{
${ }^{35}$ These Articles must be read in the light of Article 47 CFR; see Case C-300/11 ZZ v Secretary of State for the Home Department (ECLI:EU:C:2013:363; CJEU, 4 June 2013) [50]-[52].

${ }^{36}$ Article 51(1) CFR provides that its provisions 'are addressed to the ... Member States only when they are implementing Union law', which plainly covers the process of incorporation of a Regulation or implementation of a Directive; see, generally, Angela Ward, 'Article 51 - Field of Application' in Peers et al, 1413, 1415-21; see, eg, Case C-73/16 Puškár v Finančné riaditel'stvo Slovenskej republiky (ECLI:EU:C:2017:725; CJEU, 27 September 2017) (practical arrangements for the exercise of DPD remedies must not disproportionately affect the right to an effective remedy pursuant to Art 47 CFR).

${ }^{37}$ The full text of Article 19 TEU is set out in $\S 1$ of Appendix I.

${ }^{38}$ In Case C-682/15 Berlioz Investment Fund SA v Directeur de l'administration des Contributions directes (ECLI:EU:C:2017:373; CJEU, 16 May 2017) the CJEU held that the obligation imposed on Member States by Article 19 TEU 'corresponds to' (ibid [44]) the right to an effective remedy in Article 47 CFR; see also Case C-418/11 Texdata Software GmbH (ECLI:EU:C:2013:588; ECJ, 26 September 2013) [77]-[78]; Case C-583/11 P Inuit Tapiriit Kanatami v Parliament and Council (CLI:EU:C:2013:625; CJEU, 3 October 2013) [97]-[101]; Case C-562/12 Liivimaa Lihaveis MTÜ v Eesti-Läti programmi 2007-2013 Seirekomitee (ECLI:EU:C:2014:2229; CJEU,

17 September 2014) [67]-[68]. On the impact of Article 19 TEU and Article 47 CFR on private enforcement of EU law, see Sara Drake, 'More Effective Private Enforcement of EU Law Post-Lisbon: Aligning Regulatory Goals and Constitutional Values' in Drake \& Smith, ch 1.

${ }^{39}$ Articles 7 and 8 CFR, Article 16(1) TFEU, and Article 39 TEU; see $n 3$.

${ }^{40}$ Article 19 is also likely to be relied upon by the CJEU in any infringement action brought by the EU Commission, pursuant to Article 258 TFEU, against a Member State for an inaccurate or incomplete incorporation of the GDPR or pePR, or for an inaccurate or incomplete implementation of the PCJAD; see, eg, Case C-518/07 Commission v Germany [2010] ECR I-1885 (ECLI:EU:C:2010:125; CJEU, 9 March 2010) (implementation of DPD; independence of Data Protection Authority); Case C-614/10 Commission v Austria (ECLI:EU:C:2012:631; CJEU, 16 October 2012) (same); Case C-288/12 Commission v Hungary (ECLI:EU:C:2014:237; CJEU, 8 April 2014) (same). The infringement action is a remedy that has, of late, come of age; see Luca Prete and Ben Smulders, 'The Coming of Age of Infringement Procedures' (2010) 47(1) Common Market Law Review 9; see, generally, Melanie Smith, Centralised Enforcement, Legitimacy and Good Governance in the EU (Routledge 2009); Carol Harlow and Richard Rawlings, Process and Procedure in EU Administration (Hart Publishing 2014) ch 7; Laurence Gormley, 'Infringement Proceedings' in András Jakab and Dimitry Kochenov (eds), The Enforcement of EU Law and Values: Ensuring Member States' Compliance (Oxford University Press 2017) ch 4; see also ns 178 and 231.
} 
compensation in Article 82(1) GDPR, Article 56 PCJAD, and Article 22 pePR. It is to these provisions that the analysis now turns.

\section{Compensation Claims in Regulations, Directives, and the CJEU}

\subsection{The GDPR, pePR and PCJAD in Context}

Article 82(1) GDPR and Article 22 pePR both provide that a person whose rights under the Regulations have been infringed 'shall have the right to receive compensation'. On the other hand, Article 56 PCJAD provides that Member States 'shall provide for a person who has suffered damage ... to have the right to receive compensation for the damage suffered ...' ${ }^{41}$ Comparable provisions in other Regulations and Directives have been interpreted broadly by the CJEU. A similarly broad interpretation by the Court would - eventually - resolve any ambiguities in Article 82(1) GDPR, Article 22 pePR, or Article 56 PCJAD. However, the express provision of compensation claims in legislation incorporating the GDPR and pePR, in parallel with a similar claim in legislation implementing the PCJAD, would resolve those ambiguities in a timely fashion, and obviate any need for litigation to and in the CJEU.

\subsection{Regulations and Compensation}

A claim for compensation in a Regulation, such as Article 82(1) GDPR, is unusual but not unique as a matter of EU law. For example, Article 5(1)(c) of the Flight Compensation Regulation ${ }^{42}$ provides that, in the 'case of cancellation of a flight, the passengers concerned shall ... have the right to compensation by the operating air carrier in accordance with Article 7', and Article 7 provides that 'passengers shall receive compensation' according to a scale of amounts and conditions set out in that Article. In combination, Articles 5(1)(c) and 7 FCR provide an unambiguous claim for compensation. Similarly, the Rail Passengers' Regulation ${ }^{43}$ provides various claims for compensation for delayed or cancelled travel, or for personal injury. ${ }^{44}$ Other travel Regulations provide similar unambiguous formulations ${ }^{45}$ of claims for

\footnotetext{
${ }^{41}$ The full texts of Article 82 GDPR, Article 56 PCJAD, and Article 22 pePR, are set out in $\S \S 4-6$ of Appendix I; the nature of these claims is sketched in $\$ 1.2$.

${ }^{42}$ Regulation (EC) No 261/2004 of the European Parliament and of the Council of 11 February 2004 establishing common rules on compensation and assistance to passengers in the event of denied boarding and of cancellation or long delay of flights, and repealing Regulation (EEC) No 295/91 (2004 OJ L 46) [the Flight Compensation Regulation; hereafter FCR].

${ }^{43}$ Regulation (EC) No 1371/2007 of the European Parliament and of the Council of 23 October 2007 on rail passengers' rights and obligations (2007 OJ L 315).

${ }^{44}$ See, eg, ibid: Articles 13(1) (advance payments), 16(a) (reimbursement), and 17(2) (delay).

${ }^{45}$ See, eg, Article 19(5) (delay) of Regulation (EU) No 1177/2010 of the European Parliament and of the Council of 24 November 2010 concerning the rights of passengers when travelling by sea and inland waterway (2010 OJ L 334); and Articles 17 (compensation in respect of wheelchairs and other mobility equipment) and 19(2) (delay or cancellation) of Regulation (EU) No 181/2011 of the European Parliament and of the Council of 16 February 2011
} 
compensation. Outside the travel context, Article 94 of the Plant Variety Rights Regulation ${ }^{46}$ provides for a claim for 'reasonable compensation' for infringement of such rights.

\subsection{Directives and Compensation}

On the other hand, a claim for compensation in a Directive, such as that in Article 56 PCJAD, is becoming increasingly common as a matter of EU law. ${ }^{47}$ Hence, Directives provide claims for compensation for defective products, ${ }^{48}$ as well as for infringements of package holiday contracts, ${ }^{49}$ public procurement rules, ${ }^{50}$ intellectual property rights, ${ }^{51}$ competition law, ${ }^{52}$ late payments, ${ }^{53}$ and trade

on the rights of passengers in bus and coach transport and amending Regulation (EC) No 2006/2004 (2011 OJ L 55).

${ }^{46}$ Council Regulation (EC) No 2100/94 of 27 July 1994 on Community plant variety rights (1994 OJ L 227), given full effect by the European Communities (Protection of Plant Variety Rights) Regulations 2007 (SI No 273 of 2007); see ns 20 and 128.

${ }^{47}$ See, eg, Folkert Wilman, Private Enforcement of EU Law Before National Courts: The EU Legislative Framework (Edward Elgar 2015) [hereafter Wilman] ch 7; Dorota Leczykiewicz and Stephen Weatherill (eds), The Involvement of EU Law in Private Law Relationships (Hart Publishing 2017).

${ }^{48}$ Article 1 of Council Directive 85/374/EEC of 25 July 1985 on the approximation of the laws, regulations and administrative provisions of the Member States concerning liability for defective products (1985 OJ L 210) [the Products Liability Directive]; implemented in Ireland in s 2(1) of the Liability For Defective Products Act 1991; see Geraint Howells, 'Product Liability and the European Tort Landscape' in Reiner Schulze (ed), Compensation of Private Loses: The Evolution of Torts in European Business Law (Sellier 2011) [hereafter Schulze] ch 4.

${ }^{49}$ Article 5 of Council Directive 90/314/EEC of 13 June 1990 on package travel, package holidays and package tours (1990 OJ L 158) [the original Package Holidays Directive]; implemented in Ireland by s 20 of the Package Holidays and Travel Trade Act, 1995. This will be replaced by Article 14 of Directive (EU) 2015/2302 of the European Parliament and of the Council of 25 November 2015 on package travel and linked travel arrangements, amending Regulation (EC) No 2006/2004 and Directive 2011/83/EU of the European Parliament and of the Council and repealing Council Directive 90/314/EEC (2015 OJ L 326) [the new Package Holidays Directive]; this will have to be implemented before 1 July 2018 (see Article 28 of Directive (EU) 2015/2302).

${ }^{50}$ See Articles 2(1)(c), 2(6) and 2(7) of Council Directive 89/665/EEC of 21 December 1989 on the coordination of the laws, regulations and administrative provisions relating to the application of review procedures to the award of public supply and public works contracts (1989 OJ L 395) [hereafter the Public Sector Remedies Directive]; as amended by Directive 2007/66/EC of the European Parliament and of the Council of 11 December 2007 amending Council Directives 89/665/EEC and 92/13/EEC with regard to improving the effectiveness of review procedures concerning the award of public contracts (2007 OJ L 335) [hereafter the Public Sector Remedies Directive, as amended]; implemented in Ireland by Regulation 7 of the European Communities (Review Procedures for the Award of Public Supply, Public Works and Public Services Contracts) (No 2) Regulations 1994 (SI No 309 of 1994).

See also Articles 2(1)(d), 2(6) and 2(7) of Council Directive 92/13/EEC of 25 February 1992 coordinating the laws, regulations and administrative provisions relating to the application of Community rules on the procurement procedures of entities operating in the water, energy, transport and telecommunications sectors (1992 OJ L 76); as amended by Directive 2007/66/EC [hereafter the Utilities Remedies Directive, as amended]; now implemented in Ireland by Regulation 9(6) of the European Communities (Public Authorities' Contracts) (Review Procedures) Regulations 2010 (SI No 131 of 2010).

See Report from the Commission to the European Parliament and the Council on the Effectiveness of Directive 89/665/EEC and Directive 92/13/EEC, as Modified by Directive 2007/66/EC, Concerning Review Procedures in the Area of Public Procurement (COM/2017/028 final) (24 January 2017); and Catherine Donnelly, 'The New Remedial Landscape in Public Procurement in Ireland' in Duncan Fairgrieve and François Lichère (eds), Public Procurement Law: Damages as an Effective Remedy (Hart Publishing 2011) [hereafter Fairgrieve \& Lichère] $\mathrm{ch} 7$.

${ }^{51}$ Article 13 of Directive 2004/48/EC of the European Parliament and of the Council of 29 April 2004 on the enforcement of intellectual property rights (2004 OJ L 195) [the Enforcement Directive]; Piotr Machnikowski, 'Damages for the Infringement of Intellectual Property Rights under EU Law' in Schulze, ch 5. There is no direct implementation of this Directive into Irish law. However, damages provisions in intellectual property legislation 
secrets. ${ }^{54}$ Moreover, the implementations of Directives illustrate the many choices of forms and methods that national authorities can make in providing claims for compensation at national law. ${ }^{55}$ For example, some equality Directives require Member States to introduce measures to ensure compensation for loss sustained as a result of discrimination. ${ }^{56}$ Other equality Directives provide that Member States may decide that compensation can be an element of penalties or sanctions for discrimination. ${ }^{57}$ Indeed, some equality Directives - including the Recast Equal Treatment Directive - adopt both strategies. ${ }^{58}$ In these circumstances, in Ireland, the Workplace Relations Commission has extensive powers to award compensation, ${ }^{59}$ which can be quite substantial, ${ }^{60}$ though there is a cap. ${ }^{61}$ In addition, in the case of

(see, eg, s 47 of the Patents Act, 1992, s 18 of the Trade Marks Act, 1996, and ss 128 and 304 of the Copyright and Related Rights Act 2000) and common law and equitable claims and remedies (Aldi Stores $v$ Dunnes Stores [2016] IEHC 256 (15 March 2016) [79]-[87] (Cregan J)) may be relied on in appropriate cases. See also the European Communities (Enforcement of Intellectual Property Rights) Regulations 2006 (SI No 360 of 2006).

${ }^{52}$ Article 3 of the Damages Directive; Regulation 4 of the European Union (Actions for Damages for Infringements of Competition Law) Regulations 2017 (SI No 43 of 2017) (see n 16). See Petra Pohlmann, 'Private Losses in European Competition Law: Public or Private Enforcement' in Schulze, ch 9; Willem van Boom, 'The Law of Damages and Competition Law: Bien étonnées de se trouver ensemble?' in Schulze, 10; loannis Lianos, Peter Davis and Paolisa Nebbia, Damages Claims for the Infringement of EU Competition Law (Oxford University Press 2015); Sebastian Peyer, 'Compensation and the Damages Directive' (2016) 12(1) European Competition Journal 87.

${ }^{53}$ Article (6)(3) of Directive 2011/7/EU of the European Parliament and of the Council of 16 February 2011 on combating late payment in commercial transactions (recast) (2011 OJ L 48) [hereafter the Recast Late Payments Directive]; implemented in Ireland by Regulation 9(3) of the European Communities (Late Payment in Commercial Transactions) Regulations 2012 (SI No 580 of 2012).

${ }^{54}$ Article 13(3) of Directive (EU) 2016/943 of the European Parliament and of the Council of 8 June 2016 on the protection of undisclosed know-how and business information (trade secrets) against their unlawful acquisition, use and disclosure (2016 OJ L 157) [the Trade Secrets Directive]; this will have to be implemented before 9 June 2018 (see Article 19 of Directive (EU) 2016/943); see also Articles 10(2) and 11(4)-(5).

${ }^{55}$ Dorota Leczykiewicz, 'Compensatory Remedies in EU Law: The Relationship Between EU Law and National Law' in Paula Giliker (ed), Research Handbook on EU Tort Law (Edward Elgar 2017) ch 3.

${ }^{56}$ See Article 10 of Directive 2010/41/EU of the European Parliament and of the Council of 7 July 2010 on the application of the principle of equal treatment between men and women engaged in an activity in a selfemployed capacity and repealing Council Directive 86/613/EEC (2010 OJ L 180); on the remedy of compensation or damages in equality cases, see Evelyn Ellis and Philippa Watson, EU Anti-Discrimination Law, 2nd edn (Oxford University Press 2012) 305-12.

${ }^{57}$ See Article 15 of Council Directive 2000/43/EC of 29 June 2000 implementing the principle of equal treatment between persons irrespective of racial or ethnic origin (2000 OJ L 180) [the Race Equality Directive]; Article 17 of Council Directive 2000/78/EC of 27 November 2000 establishing a general framework for equal treatment in employment and occupation (2000 OJ L 303) [the Employment Equality Directive].

${ }^{58}$ See Articles 18 and 25 of Directive 2006/54/EC of the European Parliament and of the Council of 5 July 2006 on the implementation of the principle of equal opportunities and equal treatment of men and women in matters of employment and occupation (recast) (2006 OJ L 204) [the Recast Equal Treatment Directive]; see also Articles 8 and 14 of Council Directive 2004/113/EC of 13 December 2004 implementing the principle of equal treatment between men and women in the access to and supply of goods and services (2004 OJ L 373).

${ }^{59}$ See, eg, Employment Equality Act 1998, s 82 [hereafter the 1998 Act] as amended by s 36 of the Equality Act 2004; s 27 of the Equal Status Act 2000 [hereafter the 2000 Act]; and ss 40, 57, 66, 83 and 84 of the Workplace Relations Act 2015 [hereafter the 2015 Act].

${ }^{60}$ Alexandra Timmer and Linda Senden, A Comparative Analysis of Gender Equality Law in Europe (European network of legal experts in gender equality and non-discrimination) (Publications Office of the European Union 2016) 76 (very senior sales and marketing director awarded compensation of $€ 315,000$ for discriminatory dismissal during maternity leave and for distress caused by victimisation).

${ }^{61}$ See s 82(4) of the 1998 Act, as amended by s 25 of the Civil Law (Miscellaneous Provisions) Act 2011. 
discrimination on the grounds of gender, the person making the claim may seek redress by referring the case to the Circuit Court, ${ }^{62}$ where there is no cap on the level of compensation available. ${ }^{63}$ However, the implementing legislation does not expressly provide for any additional claim for compensation at private law, ${ }^{64}$ though it does acknowledge that there might be such a claim. ${ }^{65}$

On the other hand, a Directive may be silent on the issue of compensation, but national implementing legislation may still provide it. For example, although the Unfair Commercial Practices Directive ${ }^{66}$ does not in terms require it, s 74(2) of the Consumer Protection Act 2007 provides that a 'consumer who is aggrieved by a prohibited act or practice shall have a right of action for relief by way of damages, including exemplary damages'.

\subsection{Article 82(1) GDPR: 'shall have the right to receive compensation'}

Claims for compensation are typically provided for in Directives rather than Regulations, so Article 82(1) GDPR is unusual in that respect. Moreover, the formulation in that Article leaves something to be desired. It provides that a person who has suffered damage 'shall have the right to receive compensation'. At first blush, this seems clear enough, but that conclusion does not survive closer inspection. The formulation does not provide, in the present tense, that a person who has suffered damage 'has' the right to receive compensation. Instead, it provides, in a much more contingent fashion, that a plaintiff 'shall have' such a right. This provokes both the question 'how shall the plaintiff have compensation?' and the answer that further steps must be taken before a plaintiff actually has the claim.

\footnotetext{
${ }^{62}$ See s 77(3) of the 1998 Act; see also s 81E(3) of the Pensions Act 1990 as inserted by s 22 of the Social Welfare (Miscellaneous Provisions) Act 2004 and as amended by s 66(3)(b)(iii) of the Equality Act 2004; and see the provisions of the 2015 Act in $n 59$.

${ }^{63}$ Because of the case law of the CJEU referred to in ns 92-98, and of Article 18 of the Recast Equal Treatment Directive, there is no equivalent of s 82(4) of the 1998 Act (see $n$ 61) for these claims.

${ }^{64}$ There is nothing to this effect in the 1998, 2000, or 2015 Acts, the Equality Act 2004, the Equal Status (Amendment) Act 2012, the Social Welfare and Pensions Act 2014, or the Equality (Miscellaneous Provisions) Act 2015.

${ }^{65}$ At least in respect of discrimination claims pursuant to the $1998 \mathrm{Act}$, to the extent that there is also 'a claim for damages at common law', the victim of discrimination must choose between that claim and the claim before the Workplace Relations Commission (see s 101 of the 1998 Act, as amended by s 46 of the 2004 Act; no change was made to this position by the 2015 Act). In Byrne v Minister for Defence [2017] IEHC 453 (10 July 2017), in judicial review proceedings, Eager J awarded damages of $€ 824,794$ for loss of pension rights and earnings (though not general damages for distress) for breach of Articles 2(2)(c), 14(2) and 15 of the Recast Equal Treatment Directive; and he was untroubled by domestic equality legislation, by the public law nature of the proceedings, or by the private law characteristics of the damages claim.

${ }^{66}$ Directive 2005/29/EC of the European Parliament and of the Council of 11 May 2005 concerning unfair business-to-consumer commercial practices in the internal market and amending Council Directive 84/450/EEC, Directives 97/7/EC, 98/27/EC and 2002/65/EC of the European Parliament and of the Council and Regulation (EC) No 2006/2004 of the European Parliament and of the Council (2005 OJ L 149) [the Unfair Commercial Practices Directive]; see Giovanni de Cristofaro, 'Infringement of the Prohibition of Unfair Commercial Practices and Tort Law' in Schulze, ch 7; Pablo Cortés, 'Enforcing EU Consumer Policy More Effectively: A Three-Pronged Approach' in Drake \& Smith, ch 8.
} 
Although the language of Article 82(1) GDPR is contingent, it does not replicate any of the strictures, common in Directives, that Member States must 'provide' or 'ensure' or 'introduce' or 'lay down' measures to achieve an outcome, ${ }^{67}$ such as a claim for compensation. Nevertheless, the formulation in Article 82(1) GDPR is contingent upon further steps, and they are not provided in the GDPR. A plaintiff whose GDPR rights have been infringed has the right to an effective remedy pursuant to Article $47 \mathrm{CFR}$, and Member States have the corresponding obligation to provide it pursuant to Article 19 TEU. Hence, if the remedy in Article 82(1) GDPR is contingent upon further steps, then, to ensure that it is an effective remedy pursuant to Article 47 CFR, Member States will, pursuant to Article 19 TEU, have to provide the additional mechanism by which these further steps can be taken.

The Flight Compensation Regulation presents a contrast with the GDPR in this respect. Article 5(1)(c) FCR provides that, where a flight is cancelled, one 'shall ... have the right to compensation ... in accordance with Article $7^{\prime}$. That Article, in turn, supplies the additional mechanism by which the plaintiff 'shall ... have' such compensation; it provides that 'passengers shall receive compensation' (emphasis added) according to a scale set out in that Article. Hence, whilst Article 82(1) GDPR is similar to Article 5(1)(c) FCR, there is no additional provision like Article 7 FCR in the GDPR, to provide unambiguously how persons with claims pursuant to Article 82(1) GDPR 'shall receive compensation'.

Another perspective on the same problem presents itself when Article 82(1) GDPR is compared with other Articles in the GDPR itself. For example, Chapter III relates to the rights of the data subject, and these provide that the 'controller shall' do various things, ${ }^{68}$ and that 'the data subject shall have the right to' various things from the controller. ${ }^{69}$ In these cases, the rights of data subjects are given effect by obligations

\footnotetext{
${ }^{67}$ Article 56 PCJAD ('provide'); see also Article 5 of the original Package Holidays Directive ('ensure') (contrast Article 14 of the new Package Holidays Directive); Article 2(1) of the Public Sector Remedies Directive, as amended ('ensure'); Article 2(1) of the Utilities Remedies Directive, as amended ('ensure'); Article 13 of the Enforcement Directive ('ensure'); Article 3 of the Damages Directive ('ensure'); Article 13(3) of the Trade Secrets Directive ('provide'); Article 10 of Directive 2010/41/EU ('introduce'); Article 15 of the Race Equality Directive ('lay down'); Article 17 of the Employment Equality Directive ('ensure'); Articles 18 of the Recast Equal Treatment Directive ('introduce'); Article 25 ibid ('lay down'); Article 8(2) of Council Directive 2004/113/EC ('introduce'); Article 14 ibid ('lay down'); Article (6) of the Recast Late Payments Directive ('ensure'); for these Directives, see $\S 2.3$.

${ }^{68}$ For example: 'The controller shall take appropriate measures to provide ... information ...' (Article 12(1) GDPR); 'The controller shall facilitate the exercise of data subject rights under Articles 15 to 22 ' (Article 12(2)); 'The controller shall provide information ...' (Article 12(3) GDPR); 'The controller shall communicate ...' (Article 19 GDPR); and Articles 13 and 14 GDPR contain various obligations by which the controller 'shall provide' the data subject with information.

${ }^{69}$ For example: 'The data subject shall have the right to obtain from the controller ...' (Article 15(1) GDPR on the right of access by the data subject; Article 16(1) GDPR on the right to rectification; Article 17(1) GDPR on the right to erasure; Article 18(1) GDPR on the right to restriction of processing); 'The data subject shall have the right to receive ...' (Article 20(1) GDPR on to data portability); 'The data subject shall have the right to object ...' (Article
} 
on controllers; it is clear what the controllers must do; and the use of 'shall' makes it imperative that they do so. In particular, where the data subject 'shall have' a right, it is a right to something that the controller can and must do. Hence, to the question 'how shall the data subject have' that something, the answer is that the controller must do it. The practical vindication of the data subject's rights in Chapter III is therefore a very straightforward matter, entirely within the capability of the controller to provide.

On the other hand, the structure of Article 82(1) is different. Although the person who has suffered damage 'shall have the right to receive compensation', the vindication of that right is not as straightforward as the vindication of the rights in Chapter III, because this is a right that is beyond the capability of the controller to provide: it needs the intervention of the court to determine both whether the plaintiff has suffered the relevant 'material or non-material damage' and what the appropriate level of 'compensation' would be. A controller providing something to a data subject pursuant to Chapter III is simply doing exactly what the Regulation says; whereas a controller offering a sum of money to a plaintiff making a claim for compensation is trying to anticipate what a court would order. Hence, to the question 'how shall the data subject have compensation', the answer is that the controller must pay what the court orders. The practical vindication of the data subject's claim in Article 86 is not exclusively within the capability of the controller to provide, but instead requires the intervention of the court.

The Flight Compensation Regulation again presents a contrast. Article 5(1)(c) FCR provides that passengers 'shall ... have the right to compensation ... in accordance with Article 7', and Article 7 FCR goes on to provide that 'passengers shall receive compensation' according to a scale set out in that Article. As a consequence, an airline providing compensation to a passenger pursuant to Articles 5(1)(c) and 7 FCR is simply doing exactly what the Regulation says. It is the addition of Article 7 to Article 5(1)(c) that achieves this result. Although Article 82(1) GDPR is similar to Article 5(1)(c) FCR, the absence from the GDPR of an additional provision like Article 7 FCR demonstrates how the claim for compensation in Article 82(1) GDPR is more contingent than the rights in Chapter III GDPR. It falls to national law to fill this void by providing an express claim to compensation in the legislation incorporating the GDPR.

The key phrase in Article 82(1) is that the plaintiff 'shall have the right to receive compensation'. However, despite all its apparent simplicity and certainty, 'shall' is, in

21(1) GDPR); 'The data subject shall have the right not to be subject to a decision based solely on automated processing ...' (Article 22(2) GDPR). 
fact, notoriously ambiguous, ${ }^{70}$ with such a wide range of potential meanings and applications ${ }^{71}$ that it is now routinely avoided by drafters in the $\mathrm{US}^{72}$ and the UK. ${ }^{73}$ It is unsurprising, therefore, that, in the context of the GDPR, the meaning and application of 'shall' in Chapter III differs from its meaning and application in Article 82(1).

For all of these reasons, the formulation in Article 82(1) GDPR is not as unambiguous a statement of a claim for compensation as it might have been. However, it did not have to be this way. That formulation could easily have been much clearer on this issue. There could have been an additional provision like Article 7 FCR in Article 82(1) GDPR which would have made it clear beyond doubt that any additional measure such as an express claim to compensation in legislation incorporating the GDPR was not necessary. Or Article 82 GDPR could have expressly provided that a national incorporating provision was necessary. For example, the Rail Passengers' Regulation provides various claims for compensation for delayed or cancelled travel, or for personal injury, and it explicitly provides that some of those rights shall be determined or governed by national law. ${ }^{74}$ Or the English text of Article 82(1) GDPR could simply have used the present tense, as the French and German texts do. ${ }^{75}$ Indeed, of the EU's 24 official languages, ${ }^{76}$ the text of the claim for compensation in Article 82(1) GDPR seems to be in the present tense in 19 of them: 12 are like the

\footnotetext{
${ }^{70}$ James Aitken, Peter Butt and Edmund Piesse, The Elements of Drafting, 10th edn (Law Book Company 2004) ch 7; Christopher Williams, Tradition and Change in Legal English: Verbal Constructions in Prescriptive Texts (Peter Lang 2007) 177-92; Helen Xanthaki, Drafting Legislation: Art and Technology of Rules for Regulation (Hart Publishing 2014) 92-93.

${ }^{71}$ Bryan Garner, Dictionary of Legal Usage, 3rd edn (Oxford University Press 2011) [hereafter Garner] 952-55 ('shall' is 'chameleon-hued' and 'slippery'); Daniel Greenberg (ed), Stroud's Judicial Dictionary of Words and Phrases, 9th edn (Thomson Reuters Sweet \& Maxwell 2016) 2359-65. Amongst many, many meanings, 'shall' can be imperative (when it equals 'must'), predictive (when it equals 'will'), or permissive (when it equals 'may'). In Article 82(1) GDPR, 'shall' was intended to be the first, but the formulation of the rest of the Article means that it could be any of the three.

72 The Federal Plain Language Guidelines (2010) condemn 'shall' as officious, obsolete, outdated, and imprecise; as a consequence, they deprecate its use in Federal drafting (25-26) <http://www.plainlanguage.gov/howto/guidelines/bigdoc/fullbigdoc.pdf>.

${ }^{73}$ See, generally, Helen Xanthaki, Thornton's Legislative Drafting, 5th edn (Bloomsbury Professional 2013) 115. Hence, the policy of the Office of Parliamentary Counsel 'is to avoid the use of the legislative "shall"...'; see Office of the Parliamentary Counsel Drafting Guidance ([1.2.26] 4)

<https://www.gov.uk/government/uploads/system/uploads/attachment_data/file/622457/drafting_guidance_ju ne_2017.pdf>.

${ }^{74}$ See, eg, Articles 27(2) (extended damages in case of death), 29 (extended compensation for bodily harm), 30 (damages in case of death and personal injury), 32(3) (extended liability in case of cancellation, delay, or missed connections), and 60(6) (limitations).

See also Article 21 (extended claims for damages) of the Regulation (EU) No 1177/2010 (see n 45); and Article 7 (compensation for death or personal injury to passengers and loss of or damage to luggage) of Regulation (EU) No 181/2011 (ibid).

${ }^{75}$ The French text is 'a le droit d'obtenir ... reparation' (= has the right to obtain ... compensation); the German text is 'hat Anspruch auf Schadenersatz' (= is entitled to compensation).

${ }^{76}$ The formulations of the claim for compensation in Article 82(1) GDPR in the 24 official languages of the EU institutions, and literal translations into English these formulations, are set out in Appendix III, where the texts of the three procedural languages of English, French and German are highlighted in bold.
} 
French text, ${ }^{77}$ five are like the German text, ${ }^{78}$ and two others have similar formulations. ${ }^{79}$ Only five seem to have a contingent text like the English. ${ }^{80}$ But the English text was the working text as the GDPR made its way through the EU institutions, and five contingent ambiguous versions are five too many.

None of these drafting solutions was adopted. In the absence of the clarity which might thereby have been provided, the claim for compensation in Article 82(1) GDPR remains contingent upon further steps. Since the additional mechanism by which these further steps can be taken is not provided in the GDPR, it falls to the Member States, pursuant to Article 19 TEU, to fill this void by providing an express claim to compensation in legislation incorporating the GDPR. Such a provision ought therefore to be included in the next draft of the Irish Government's Scheme, to ensure that plaintiffs 'shall' have effective claims to compensation pursuant to Article 82(1) GDPR.

\subsection{Compensation Claims in the CJEU}

Of course, the CJEU might very well solve the problem. Employing its customary teleological approach to interpretation, ${ }^{81}$ it has provided expansive analyses of claims for compensation in a wide range of Regulations and Directives. The details of these analyses may differ across various policy areas, but the Court's general approach to compensation has been consistently expansive, and the approach may now be justified by the right to an effective judicial remedy pursuant to Article 47 CFR.

\footnotetext{
${ }^{77}$ The plaintiff 'has the right to [receive/obtain] compensation' (Czech, Danish, Dutch, French, Finnish, Italian, Latvian, Lithuanian, Polish, Portuguese, Romanian, and Slovenian); see Appendix III.

${ }^{78}$ The plaintiff 'is entitled to compensation' (Bulgarian, Estonian, German, Greek, and Hungarian); see Appendix III.

${ }^{79}$ The plaintiff 'has the right to compensation' (Croatian) or 'has a claim for compensation' (Slovak); see Appendix III.

Even if the nuances of the context in Article 82 GDPR mean that any one of the formulations in this footnote or the previous two could be translated along the lines set out in any of the other two footnotes, this would not change the essential point that the formulations in all three footnotes are in the present tense, and are therefore not as contingent as the formulations in the next footnote.

${ }^{80}$ The plaintiff 'shall have the right to [receive] compensation' (English, Maltese, Spanish, and Swedish); the plaintiff 'shall be entitled to compensation' (Irish); the GDPR has EEA relevance, and the current Icelandic and Norwegian drafts translate into English as 'shall be entitled to [receive] compensation': see Appendix III. Note that English was the working language of the GDPR drafting process; all of the documents in the Procedure File are in English; see <http://www.europarl.europa.eu/oeil/popups/ficheprocedure.do?reference=2012/0011(COD)>.

${ }^{81}$ See, eg, Nial Fennelly, 'Legal Interpretation at the European Court of Justice' (20)3 Fordham International Law Journal 656 (1996); Anthony Arnull, The European Union and its Court of Justice, 2nd edn (Oxford University Press 2006) ch 16.
} 
For example, the CJEU has provided expansive interpretations of claims for compensation pursuant to the Plant Variety Rights Regulation ${ }^{82}$ as well as to various travel Regulations. Take, again, the claim for compensation in Articles 5(1)(c) and 7 FCR: the Court has held that the claim must be interpreted broadly, and that exceptions and derogations have to be interpreted narrowly..$^{83}$ In particular, in Sturgeon, ${ }^{84}$ the CJEU held that provisions conferring claims for compensation must be interpreted broadly to provide a high level of protection for air passengers. The Court therefore held that passengers whose flights suffer a long delay must be treated as passengers whose flights are cancelled, so that they can rely on the claim for compensation in Articles 5 and 7 CFR.

The CJEU has also provided expansive interpretations of claims for compensation in the context of various Directives, such as the Products Liability Directive, ${ }^{85}$ the Enforcement Directive, ${ }^{86}$ and the public procurement remedies Directives. ${ }^{87}$ For example, in Commission v Portugal ${ }^{88}$ and Stadt Graz, ${ }^{89}$ the Court held that the right to damages pursuant to the Public Sector Remedies Directive could not be made conditional on the infringement being culpable or a result of fault. Furthermore, in

${ }^{82}$ Case C-509/10 Geistbeck v Saatgut-Treuhandverwaltungs GmbH (ECLI:EU:C:2012:416; CJEU, 5 July 2012) [37], [43]; Case C-481/14 Hansson v Jungpflanzen Grünewald GmbH (ECLI:EU:C:2016:419; CJEU, 9 June 2016) [31][33], [43], [52].

${ }^{83}$ Case C-549/07 Wallentin-Hermann v Alitalia [2008] ECR-I 11061 (ECLI:EU:C:2008:771; ECJ, 22 December 2008) [17], [20]; Case 12/11 McDonagh v Ryanair (ECLI:EU:C:2013:43; CJEU, 31 January 2013) [28], [31], [63]; Case C257/14 van der Lans v Koninklijke Luchtvaart Maatschappij NV (ECLI:EU:C:2015:618; CJEU, 17 September 2015) [26], [35]; Case C-315/15 Pešková v Travel Service a.s. (ECLI:EU:C:2017:342; CJEU, 4 May 2017) [25]; Case C302/16 Krijgsman v Surinaamse Luchtvaart Maatschappij NV (ECLI:EU:C:2017:359; CJEU, 11 May 2017) [27]-[31]. ${ }^{84}$ Joined Cases C-402/07 and C-432/07 Sturgeon v Condor Flugdienst GmbH and Böck v Air France SA [2009] ECR-I 10932 (ECLI:EU:C:2009:716; CJEU, 9 November 2009) [44]-[45], [61], [69]; see also Joined Cases C-581/10 Nelson v Deutsche Lufthansa AG and C-629/10 TUI Travel plc v Civil Aviation Authority (ECLI:EU:C:2012:657; CJEU, 23 October 2012) [72], [92]; Case C-11/11 Air France SA v Folkerts (ECLI:EU:C:2013:106; CJEU, 26 February 2013) [32], [42]; Case C-559/16 Bossen v Brussels Airlines (ECLI:EU:C:2017:644; CJEU, 7 September 2017) [19][33].

${ }^{85}$ Case C-203/99 Veedfald v Århus Amtskommune [2001] ECR I-3569 (ECLI:EU:C:2001:258; ECJ, 10 May 2001) [27]; Joined Cases C-503/13 and C-504/13 Boston Scientific Medizintechnik GmbH v AOK Sachsen-Anhalt (ECLI:EU:C:2015:148; CJEU, 5 March 2015) [45]-[50].

${ }^{86}$ Case C-280/15 Nikolajeva v Multi Protect OÜ (ECLI:EU:C:2016:467; CJEU, 22 June 2016) [54]; Case C-99/15 Christian Liffers v Producciones Mandarina SL (ECLI:EU:C:2016:173; CJEU, 17 March 2016) (full compensation includes both royalties and moral prejudice); Case C-367/15 Stowarzyszenie 'Oławska Telewizja Kablowa' $v$ Stowarzyszenie Filmowców Polskich (ECLI:EU:C:2017:36; CJEU, 25 January 2017).

${ }^{87}$ See Saulius Lukas Kalèda, 'Claims for Damages in EU Procurement and Effective Protection of Individual Rights' (2014) 39(2) European Law Review 193; Steen Treumer, 'Basis and Conditions for a Damages Claim for Breach of the EU Public Procurement Rules' in Fairgrieve \& Lichère, ch 8; Anthony Collins, 'Damages in Public Procurement - An Illusory Remedy?' in Kieran Bradley, Noel Travers and Anthony Whelan (eds), Of Courts and Constitutions Liber Amicorum in Honour of Nial Fennelly (Oxford 2014) ch 21; Hanna Schebesta, Damages in EU Public Procurement Law (Springer-Verlag GmbH 2015) ch 4.

${ }^{88}$ Case C-275/03 Commission v Portugal (ECLI:EU:C:2004:632; CJEU, 14 October 2004).

${ }^{89}$ Case C-314/09 Stadt Graz v Strabag AG [2010] ECR I-8769 (ECLI:EU:C:2010:567; ECJ, 30 September 2010). See also Case C-568/08 Combinatie Spijker Infrabouw-De Jonge Konstruktie v Provincie Drenthe [2010] ECR I-12655 (ECLI:EU:C:2010:751; ECJ, 9 December 2010); Dekra Eireann Teoranta v Minister for the Environment and Local Government [2003] 2 IR 270, [2003] 2 ILRM 210, [2003] IESC 25 (4 April 2003); Clare Civil Engineering v Mayo County Council [2004] IEHC 135 (9 July 2004); Nuclear Decommissioning Authority v EnergySolutions EU Ltd [2017] 1 WLR 1373, [2017] UKSC 34 (11 April 2017). 
Leitner, ${ }^{90}$ the Court held that Article 5 of the original Package Holidays Directive conferred on consumers a claim for compensation for non-material damage, such as distress.

The CJEU has provided its most expansive interpretations of claims for compensation in the context of various equality Directives. For example, even though the original Equal Treatment Directive ${ }^{91}$ did not expressly provide for compensation, nevertheless, in Marshall, ${ }^{92}$ the Court held that, if a Member State decided to provide for compensation for discriminatory dismissal contrary to that Directive, then that compensation 'must enable the loss and damage actually sustained as a result of the discriminatory dismissal to be made good in full'. ${ }^{93}$ Again, in Dekker ${ }^{94}$ and Draehmpaehl, ${ }^{95}$ the Court held that infringement of the Directive was sufficient to give rise to a remedy, so that domestic law could not make compensation subject to a requirement of fault. As a consequence of such cases, the claim for compensation for discrimination has been expressly included in subsequent equality Directives $^{96}$; and, in Camacho, ${ }^{97}$ the Court reaffirmed the Marshall approach in the context of the express claim for compensation in the Recast Equal Treatment Directive.

\footnotetext{
${ }^{90}$ Case C-168/00 Leitner v TUI Deutschland GmbH [2002] ECR I-1631 (ECLI:EU:C:2002:163; ECJ, 12 March 2002).

${ }^{91}$ Council Directive 76/207/EEC of 9 February 1976 on the implementation of the principle of equal treatment for men and women as regards access to employment, vocational training and promotion, and working conditions (1976 OJ L 39) [the original Equal Treatment Directive].

${ }^{92}$ Case C-271/91 Marshall v Southampton and South-West Hampshire Area Health Authority (Marshall II) [1993] ECR I-4367 (ECLI:EU:C:1993:335; ECJ, 2 August 1993).

${ }^{93}$ Marshall (ibid) [26]; Case 14/83 von Colson v Land Nordrhein-Westfalen [1984] ECR 1891 (ECLI:EU:C:1984:153; ECJ, 10 April 1984) [28] (to be an effective deterrent, compensation must be adequate in relation to damage suffered); Case 79/83 Harz v Deutsche Tradax GmbH [1984] ECR 1921 (ECLI:EU:C:1984:155; ECJ, 10 April 1984) [28] (same); Case C-460/06 Paquay v Société d'architectes Hoet and Minne SPRL [2007] ECR I-8511 (ECLI:EU:C:2007:601; ECJ, 11 October 2007) [46]; Case C-407/14 Camacho v Securitas Seguridad España SA (ECLI:EU:C:2015:831; CJEU, 17 December 2015) [32]-[35]; see also Case C-54/07 Centrum voor gelijkheid van kansen en voor racismebestrijding v Firma Feryn NV [2008] ECR I-5187 (ECLI:EU:C:2008:397; CJEU, 10 July 2008) [35]-[40] (broad interpretation of the sanctions, including compensation, provided in Article 15 of the Race Equality Directive).

${ }^{94}$ Case C-177/88 Dekker v Stichting Vormingscentrum voor Jong Volwassenen (VJV-Centrum) Plus [1990] ECR I3941 (ECLI:EU:C:1990:38; ECJ, 8 November 1990).

${ }^{95}$ Case C-180/95 Draehmpaehl v Urania Immobilienservice OHG [1997] ECR I-2195 (ECLI:EU:C:1997:208; ECJ, 22 April 1997).

${ }^{96}$ In particular, the claim for compensation had been added to Articles 6 and $8 \mathrm{~d}$ of the original Equal Treatment Directive by Articles 6 and 7 of Directive 2002/73/EC of the European Parliament and of the Council of 23 September 2002 amending Council Directive 76/207/EEC on the implementation of the principle of equal treatment for men and women as regards access to employment, vocational training and promotion, and working conditions (2002 OJ L 269) [the Sexual Harassment Amendment Directive]. These provisions, in turn, were replaced by those in the Recast Equal Treatment. They have been broadly replicated in other equality Directives (for these Directives, see notes 56-58 and 91).

${ }^{97}$ Case C-407/14 Camacho v Securitas Seguridad España SA (ECLI:EU:C:2015:831; CJEU, 17 December 2015) [29][33]. Indeed, in such circumstances, the Directive permits, though it does not require, punitive damages: ibid [37]. The Enforcement Directive similarly permits, but does not require, punitive damages; see Case C-367/15 Stowarzyszenie 'Oławska Telewizja Kablowa'v Stowarzyszenie Filmowców Polskich (ECLI:EU:C:2017:36; CJEU, 25 January 2017).
} 
It was established in litigation concerning the original Equal Treatment Directive, ${ }^{98}$ and affirmed many times thereafter, ${ }^{99}$ that the right to an effective judicial remedy is a general principle of EU law, ${ }^{100}$ and it is now embodied ${ }^{101}$ in Article 47 CFR. $^{102}$ Consequently, the echoes of Article 47 CFR in the equality Directives and associated case law are manifestly not coincidental. ${ }^{103}$ This is especially so insofar as compensation for infringement of the rights protected by those Directives is concerned. ${ }^{104}$ In particular, in Draehmpaehl, the CJEU emphasised that

${ }^{98}$ Case 222/84 Johnston v Chief Constable of the Royal Ulster Constabulary [1986] ECR 1651 (ECLI:EU:C:1986:206; ECJ, 15 May 1986) [18]; see, generally, Anthony Arnull, 'The Principle of Effective Judicial Protection in EU law: An Unruly Horse?' (2011) 36(1) European Law Review 51.

${ }^{99}$ Case C-222/86 Union nationale des entraîneurs et cadres techniques professionnels du football $v$ Heylens [1987] ECR 4097 (ECLI:EU:C:1987:442; ECJ, 15 October 1987) [14]; Joined Cases C-87/90, C-88/90 and C-89/90 Verholen v Sociale Verzekeringsbank Amsterdam [1991] ECR I-3757 (ECLI:EU:C:1991:314; ECJ, 11 July 1991) [24]; Case C-97/91 Oleificio Borelli SpA v Commission [1992] ECR I-6313 (ECLI:EU:C:1992:491; ECJ, 3 December 1992) [14]; Case C-1/99 Kofisa Italia Srl v Ministero delle Finanze [2001] ECR I-207 (ECLI:EU:C:2001:10; ECJ, 11 January 2001) [46]; Case C-226/99 Siples Srl v Ministero delle Finanze [2001] ECR I-277 (ECLI:EU:C:2001:14; ECJ, 11 January 2001) [17]; Case C-424/99 Commision v Austria [2001] I-9285 (ECLI:EU:C:2001:642; ECJ, 27 November 2001) [45]; Case C-459/99 Mouvement contre le racisme, I'antisémitisme et la xénophobie ASBL v Belgium [2002] ECR I-6591 (ECLI:EU:C:2002:461; ECJ, 25 July 2002) [101]; Case C-50/00 P Unión de Pequeños Agricultores v Council [2002] I-6677 (ECLI:EU:C:2002:462; ECJ, 25 July 2002) [39]; Case C-467/01 Ministero delle Finanze v Eribrand [2003] ECR I-6471 (ECLI:EU:C:2003:364; ECJ, 19 June 2003) [61]; Case C-13/01 Safalero Srl v Prefetto di Genova [2003] ECR I-8679 (ECLI:EU:C:2003:447; ECJ, 11 September 2003) [50], [56]; Case C-506/04 Wilson v Ordre des avocats du barreau de Luxembourg [2006] ECR I-8613 (ECLI:EU:C:2006:587; ECJ, 19 September 2006) [46].

${ }^{100}$ See, generally, Ingolf Pernice, 'The Right to Effective Judicial Protection and Remedies in the EU' in Allan Rosas, Egils Levits, and Yves Bot (eds), The Court of Justice and the Construction of Europe: Analyses and Perspectives on Sixty Years of Case-law (TMC Asser Press 2013) [hereafter Rosas, Levits \& Bot] 31; see generally Takis Tridimas, The General Principles of EU Law, 3rd edn (Oxford University Press forthcoming) chs 7 and 11. ${ }^{101}$ Case C-432/05 Unibet v Justitiekanslern [2007] ECR I-2271 (ECLI:EU:C:2007:163; ECJ, 13 March 2007) [37]; Joined Cases C-402/05 P and C-415/05 P Kadi and Al Barakaat International Foundation v Council and Commission (Kadi I) [2008] I-06351 (ECLI:EU:C:2008:461; ECJ, 3 September 2008) [335]; Case C-385/07 P Der Grüne Punkt - Duales System Deutschland v Commission [2009] ECR I-6155 (ECLI:EU:C:2009:456; ECJ, 16 July 2009) [177]-[179]; Case C-12/08 Mono Car Styling v Odemis [2009] ECR I-6653 (ECLI:EU:C:2009:466; ECJ, 16 July 2009) [47]; Case C-279/09 DEB Deutsche Energiehandels- und Beratungsgesellschaft mbH v Germany [2010] ECR I-13849 (ECLI:EU:C:2010:811; CJEU, 22 December 2010) [29]-[31]; Joined Cases C-317/08 to C-320/08 Alassini v Telecom Italia SpA (ECLI:EU:C:2010:146; CJEU, 18 March 2010) [61]; Case C-457/09 Chartry v Belgium [2011] ECR I-819 (ECLI:EU:C:2011:101; CJEU, 1 March 2011) [25]; Case C-69/10 Samba Diouf [2011] ECR I-7151 (ECLI:EU:C:2011:524; CJEU, 28 July 2011) [49]; Case C-199/11 Europese Gemeenschap v Otis NV (ECLI:EU:C:2012:2390; CJEU, 6 November 2012) [46]; Case C-334/12 RX-II Réexamen Arango Jaramillo v European Investment Bank (ECLI:EU:C:2013:134; CJEU, 28 February 2013) [40]-[42]; Case C-93/12 ET Agrokonsulting-04-Velko Stoyanov v Izpalnitelen direktor na Darzhaven fond 'Zemedelie' - Razplashtatelna agentsia (ECLI:EU:C:2013:432; CJEU, 27 June 2013) [59]; Joined Cases C-584/10 P, C-593/10 P and C-595/10 P Commission v Kadi (Kadi II) (ECLI:EU:C:2013:518; CJEU, 18 July 2013) [98]-[100]; C-583/11 P Inuit Tapiriit Kanatami v Parliament and Council (CLI:EU:C:2013:625; CJEU, 3 October 2013); see also notes 12, 18, 34-40, 120-22, and 153.

${ }^{102}$ Marek Safjan and Dominik Düsterhaus, 'A Union of Effective Judicial Protection: Addressing a Multi-level Challenge through the Lens of Article 47 CFR EU' (2014) 33(1) Yearbook of European Law 3; Sacha Prechal, 'The Court of Justice and Effective Judicial Protection: What Has the Charter Changed?' in Christophe Paulussen, Tamara Takács, Vesna Lazić, and Ben Van Rumpuy (eds), Fundamental Rights in International and European Law: Public and Private Law Perspectives (TMC Asser Press 2016) ch 7.

${ }^{103}$ See, eg, Marshall (n 92) [24] (real and effective judicial protection); Case C-460/06 Paquay v Société d'architectes Hoet + Minne SPRL [2007] ECR I-8511 (ECLI:EU:C:2007:601; ECJ, 11 October 2007) [45], [49] (same); Case C-63/08 Pontin v T-Comalux SA [2009] ECR I-10467 (ECLI:EU:C:2009:666; ECJ, 29 October 2009) [41]. ${ }^{104}$ See the cases cited in note 93. 
compensation in such circumstances 'must be such as to guarantee real and effective judicial protection'. ${ }^{105}$

Hence, the expansive interpretations of claims for compensation provided by the CJEU (especially, but not exclusively, in the equality cases) reflects and is supported by the right to an effective judicial remedy in Article 47 CFR. Those cases, and that Article, would plainly justify an expansive interpretation of Article 82(1) GDPR that avoids any contingency in the text. Indeed, Recital 146 GDPR places Article 82 firmly in the context of these lines of compensation authority; it provides:

... The concept of damage should be broadly interpreted in the light of the case-law of the Court of Justice in a manner which fully reflects the objectives of this Regulation. ... Data subjects should receive full and effective compensation for the damage they have suffered. ... ${ }^{106}$

This makes the intention behind Article 82 GDPR pellucidly clear, and it is borne out by the 19 of the EU's 24 official languages that are in the present tense rather than in more contingent terms. ${ }^{107}$ Where a provision in an EU text is ambiguous, the CJEU gives preference to the interpretation that ensures that the provision is effective. ${ }^{108}$ In particular, where there is a divergence between different language versions of an $\mathrm{EU}$ text, ${ }^{109}$ the wording in one language version cannot serve as the sole basis for the interpretation of that provision, or be made to override the other language versions. ${ }^{110}$ Instead, to achieve a uniform interpretation across all EU languages, the provision in question must be interpreted teleologically, by reference to the purpose and general scheme of the rules of which it forms part. ${ }^{111}$

\footnotetext{
${ }^{105}$ Note 95 [25].

${ }^{106}$ The full text of Recital 8 GDPR is set out in $\S 4$ of Appendix I. Recital 88 PCJAD is in the same terms, and the full text of that recital is set out in $\S 5$ of Appendix I.

${ }^{107}$ See text with and in notes 75-80.

${ }^{108}$ Case 187/87 Saarland v Ministre de I'Industrie, des Postes et Télécommunications et du Tourisme [1988] ECR 5013 (ECLI:EU:C:1988:439; ECJ, 22 September 1988) [19]; Case C-437/97 Evangelischer Krankenhausverein Wien $\checkmark$ Abgabenberufungskommission Wien [2000] ECR I-1157 (ECLI:EU:C:2000:110; ECJ, 9 March 2000) [41].

${ }^{109}$ Mattias Derlén, Multilingual Interpretation of European Union Law (Kluwer Law International 2007, 2009) chs 1-3.

${ }^{110}$ Case C-149/97 Institute of the Motor Industry v Commissioners of Customs and Excise [1998] ECR I-7053 (ECLI:EU:C:1998:536; ECJ, 12 November 1998) [16]; Case C-187/07 Endendijk [2008] ECR I-2115 (ECLI:EU:C:2008:197; ECJ, 3 April 2008) [23]; Case C-558/11 SIA Kurcums Metal v Valsts ieñemumu dienests (ECLI:EU:C:2012:721; CJEU, 15 November 2011) [48]; Case C-173/15 GE Healthcare GmbH v Hauptzollamt Düsseldorf (ECLI:EU:C:2017:195; CJEU, 9 March 2017) [65].

${ }^{111}$ Case 30/77 R v Bouchereau [1977] ECR 1999 (ECLI:EU:C:1977:172; ECJ, 27 October 1977) [14]; Case C-372/88 Milk Marketing Board v Cricket St Thomas [1990] ECR I-1345 (ECLI:EU:C:1990:140; ECJ, 27 March 1990) [19]; Case C-434/97 Commission v France [2000] ECR I-1129 (ECLI:EU:C:2000:98; ECJ, 24 February 2000) [22]; Case C437/97 Evangelischer Krankenhausverein Wien v Abgabenberufungskommission Wien [2000] ECR I-1157 (ECLI:EU:C:2000:110; ECJ, 9 March 2000) [42]; Case C-482/98 Italy v Commission [2000] ECR I-10861 (ECLI:EU:C:2000:672; ECJ, 7 December 2000) [49]; Case C-1/02 Privat-Molkerei Borgmann GmbH \& Co KG v Hauptzollamt Dortmund [2004] ECR I-3219 (ECLI:EU:C:2004:202; ECJ, 1 April 2004) [25]; Case C-510/10 DR and TV2 Danmark A/S v NCB - Nordisk Copyright Bureau (ECLI:EU:C:2012:244; CJEU, 26 April 2012) [45]; Case C89/12 Bark v Galileo Joint Undertaking (ECLI:EU:C:2013:276; CJEU, 25 April 2013) [40]; Case C-257/14 van der
} 
Given that the text of Article 82(1) GDPR is not ambiguous in 19 of the official languages, that the CJEU routinely provides expansive interpretations of compensation claims, and that plaintiffs are entitled to an effective judicial remedy pursuant to Article 47 CFR, it follows that an expansive interpretation by the CJEU of the claim for compensation in Article 82(1) GDPR, teleologically rejecting the contingent nature of the claim inherent in the English text, is inevitable. However, such a conclusion by the CJEU is inevitable only if it is asked; and, unless and until it is, there is the potential for unnecessary uncertainty. Rather than leaving the matter to the vagaries of litigation to - and in - the CJEU, it would be better to have this matter put beyond doubt by the express provision of a claim for compensation in national legislation incorporating the GDPR and the pePR.

\subsection{Resolving Ambiguity by Incorporation}

Because Regulations are directly applicable, there is usually no need for Member States to take any further action ${ }^{112}$ by means, for example, of national legislation. Indeed, they must not do anything to obstruct the direct applicability of Regulations ${ }^{113}$; and they must not seek to exempt themselves from their terms or modify their application. ${ }^{114}$ However, the CJEU has recognised that the provisions of some Regulations may necessitate measures by Member States, ${ }^{115}$ provided that such measures do not obstruct its direct applicability or conceal its EU nature. ${ }^{116}$ In particular, in the case of a difficulty in interpreting a Regulation, national law may provide clarification, provided that this complies with EU law, and does not bind the CJEU. ${ }^{117}$ Recital 8 GDPR ${ }^{118}$ seeks to capture this line of authority. It acknowledges that Member States will incorporate elements of the GDPR into national law.

\footnotetext{
Lans v Koninklijke Luchtvaart Maatschappij NV (ECLI:EU:C:2015:618; CJEU, 17 September 2015) [25]; Case C113/15 Breitsamer und Ulrich GmbH \& Co KG v Landeshauptstadt München (ECLI:EU:C:2016:718; CJEU, 22 September 2016) [58].

${ }^{112}$ See note 19.

${ }^{113}$ Case 34/73 Fratelli Variola SpA v Amministrazione italiana delle Finanze [1973] ECR I-981 (ECLI:EU:C:1973:101; ECJ, 10 October 1973) [9]-[11]; Case C-539/10 P Stichting Al-Aqsa v Council (ECLI:EU:C:2012:711; CJEU, 15 November 2012) [87].

${ }^{114}$ Case 18/72 NV Granaria Graaninkoopmaatschappij v Produktschap voor Veevoeder (ECLI:EU:C:1972:108; ECJ, 30 November 1972) [14]-[18]; Case 39-72 Commission v Italy [1973] ECR 101 (ECLI:EU:C:1973:13; ECJ, 7 February 1973) [4], [22]-[23] (practical difficulties in putting a Regulation into effect cannot permit a Member State unilaterally to opt out of observing its obligations).

${ }^{115}$ Case 230/78 SpA Eridania-Zuccherifici nazionali v Minister of Agriculture and Forestry [1979] ER 2749 (ECLI:EU:C:1979:216; ECJ, 27 September 1979) [34]; Case C-403/98 Azienda Agricola Monte Arcosu Srl v Regione Autonoma della Sardegna [2001] ECR I-103 (ECLI:EU:C:2001:6, ECJ, 11 January 2001) [26]; C-278/02 Herbert Handlbauer GmbH [2004] ECR I-6171 (ECLI:EU:C:2004:388; ECJ, 24 June 2004) [25]--[26].

${ }^{116}$ Case C-113/02 Commission v Netherlands [2004] ECR I-9707 (ECLI:EU:C:2004:616; ECJ, 14 October 2004) [16]; Case C-316/10 Danske Svineproducenter v Justitsministeriet [2011] ECR I-13721 (ECLI:EU:C:2011:863; ECJ, 21 December 2011) [38]-[42].

${ }^{117}$ Case 94/77 Fratelli Zerbone Snc v Amministrazione delle finanze dello Stato [1978] ECR 99 (ECLI:EU:C:1978:17; ECJ, 31 January 1978) [27].

${ }^{118}$ The full text of Recital 8 GDPR is set out in $\S 4$ of Appendix I.
} 
Nevertheless, it provides that they may do so only 'as far as necessary for coherence and for making the national provisions comprehensible to the persons to whom they apply'. Since Article 82(1) GDPR is contingent and ambiguous, the express provision of a claim for compensation in national incorporating legislation is clearly necessary to clarify that such a claim is available, and to ensure that it is coherent and comprehensible to those who would seek to rely on it.

Indeed, not only can Member States address ambiguities in Regulations by providing clarification in national incorporations, but they may even have a responsibility to do so where those ambiguities relate to legal remedies for EU rights. Member States have a responsibility to establish a system of legal remedies to ensure respect for the fundamental right to effective judicial protection. ${ }^{119}$ This responsibility flows both from the general principle ${ }^{120}$ of an effective remedy for infringements of EU rights now embodied in Article $47 \mathrm{CFR},{ }^{121}$ and from the State's obligation pursuant to Article 19 TEU to provide remedies sufficient to ensure the effective legal protection of those rights. ${ }^{122}$ This responsibility will be met, and the contingent nature of Article 82(1) will be resolved, if Member States provide an express a claim for compensation in national incorporating legislation.

Article 22 pePR currently provides that anyone 'who has suffered material or nonmaterial damage ... shall have the right to receive compensation'. However, since it is still only a proposed Regulation, there is still time to amend it, so that Article 22 could come into line with the present tense in the French and German texts of Article 82(1) GDPR rather than the contingent draft of the English text of that Article. However, if Article 22 pePR remains unchanged, or if it is amended along the lines of one of the current proposals, ${ }^{123}$ then the same considerations will arise, and the

\footnotetext{
${ }^{119}$ Case C-50/00 P Unión de Pequeños Agricultores v Council [2002] I-6677 (ECLI:EU:C:2002:462; ECJ, 25 July 2002) [41]; Case C-263/02 P Commission v Jégo-Quéré \& Cie SA [2004] ECR I-03425 (ECLI:EU:C:2004:210; ECJ, 1 April 2004) [31]; Case C-583/11 P Inuit Tapiriit Kanatami v Parliament and Council (CLI:EU:C:2013:625; CJEU, 3 October 2013) [97]-[100]. See also the responsibility of Member States to ensure that EU rights are effectively protected in every case; Case 179/84 Bozzetti v Invernizzi SpA [1985] ECR 2301 (ECLI:EU:C:1985:306; ECJ, 9 July 1985) [17]; Case C-

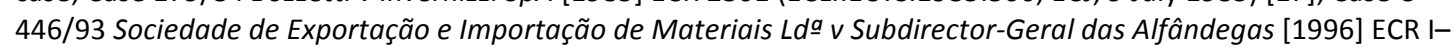
73 (ECLI:EU:C:1996:10; ECJ, 18 January 1996) [32]; Case C-54/96 Dorsch Consult Ingenieursgesellschaft v Bundesbaugesellschaft Berlin [1997] ECR I-4961 [40]; Case C-397/11 Erika Jörös v Aegon Magyarország Hitel Zrt (ECLI:EU:C:2013:340; CJEU, 30 May 2013) [50].

${ }^{120}$ Case C-50/00 P Unión de Pequeños Agricultores v Council [2002] I-6677 (ECLI:EU:C:2002:462; ECJ, 25 July 2002) [39]-[41]; Case C-263/02 P Commission v Jégo-Quéré \& Cie SA [2004] ECR I-03425 (ECLI:EU:C:2004:210; ECJ, 1 April 2004) [29]-[31]; Case C-268/06 Impact v Minister for Agriculture and Food [2008] ECR I-2483 (ECLI:EU:C:2008:223; ECJ, 15 April 2008) [43]-[45].

${ }^{121}$ Joined Cases C-317/08 to C-320/08 Alassini v Telecom Italia SpA (ECLI:EU:C:2010:146; CJEU, 18 March 2010) [47], [61]. On Article 47 CFR, see also notes 12, 18, 34-40, 98-105, and 153.

${ }^{122}$ Case C-583/11 P Inuit Tapirit Kanatami v Parliament and Council (CLI:EU:C:2013:625; CJEU, 3 October 2013) [97]-[101]; $R$ (on the application of ClientEarth) v Secretary of State for the Environment, Food and Rural Affairs ECLI:EU:C:2014:2382; CJEU, 19 November 2014) [52]; see, generally, notes 37-38.

${ }^{123}$ Amendments to the Commission's Proposal (n 29) have been put forward by the Parliament and Council, so the issue will eventually be resolved in trilogue. The progress of the pePR can be tracked in the Procedure File at
} 
same conclusion will hold: national legislation incorporating the pePR will have to include an express provision of a claim for compensation.

While the EU institutions discuss the pePR, national legislators are getting on with the task incorporating the GDPR, and they are divided on the issue of whether national incorporations ought to provide for an express claim to compensation. ${ }^{124}$ On the one hand, such express claims are included in legislation in Austria, in draft Bills in Hungary, the Netherlands, Poland, Romania, Slovakia, Spain, and the UK, and in a report in Sweden. ${ }^{125}$ On the other, no such express claims appear in legislation in Germany and France, in draft Bills in Belgium, Latvia, Lithuania, and Luxembourg, or in reports in Denmark, Estonia, and Finland. This means that, of the eighteen Member States (other than Ireland) which have, so far, produced legislation, Bills, or reports on GDPR incorporation, nine have provided for express claims to compensation, and nine have not.

In Ireland, the first draft of national incorporating legislation is provided by the Scheme, Head 91 of which makes provision for judicial remedies. Unless and until the CJUE gives Article 82(1) an expansive interpretation, the potential for uncertainty is very great; and certainty, coherence and comprehensibility would be best served by the express provision of a claim for damages in Head 91. Furthermore, if Article $82(1)$ is too ambiguous to be saved by an expansive interpretation, then the express provision of a claim for damages in Head 91 would - once again - clearly be necessary. Hence, Head 91 ought to include an express claim for damages just as an express claim to compensation to implement Article 56 PCJAD is provided in Head 58 of the Scheme. The question that arises, therefore, is whether Heads 58 and 91 of the Scheme successfully provide for such claims for compensation, and seeking an answer to that question is the work of the next Part of this article.

\section{Compensation Claims in national legislation}

\subsection{Incorporating the GDPR and pePR, and Implementing the PCJAD, into Domestic Law}

In principle, the simplest solution to the ambiguity of Article 82(1) GDPR is to incorporate it into national law. That incorporation, and the implementation of Article 56 PCJAD should, as far as possible, adopt a common framework, and that

\footnotetext{
<http://www.europarl.europa.eu/oeil/popups/ficheprocedure.do?lang=\&reference=2017/0003(COD) > and the fate of Article 22 peR will be updated at <http://www.cearta.ie/2017/09/compensation-for-breach-of-theproposed-eprivacy-regulation/>.

${ }^{124}$ Links to Acts or Bills in Member States incorporating the GDPR are set out in Appendix III.

${ }^{125}$ It may be worth noticing that English, Spanish, and Swedish, are three of the 5 'shall' texts ( $\mathrm{n} 80$ ). Malta has yet to publish a Bill. Irish is the fifth 'shall' text, and the Irish draft Scheme (in English) is considered in Part 3.
} 
framework should be replicated in any incorporation of Article 22 pePR.

Unfortunately, the relevant provisions of the General Scheme of the Data Protection Bill 2017 are incomplete in this regard, and should be amended accordingly.

\subsection{The General Scheme of the Data Protection Bill 2017}

\subsubsection{Articles 79 and 82 GDPR, and Head 91 of the Scheme}

Article 79 GDPR provides for a right to an effective judicial remedy against a controller or processor, and Article 82 provides for a claim to compensation as an important aspect of that effective judicial remedy. ${ }^{126}$ Head 91 of the Scheme is directed towards these Articles. ${ }^{127}$

Head 91(1) provides what it describes as 'a data protection action' to data subjects whose rights under the GDPR or its incorporating legislation are infringed. Head 91(2) provides jurisdiction to the Circuit Court, concurrently with the High Court, to hear such actions. Head 91(3) provides:

In a data protection action under this Head, the Circuit Court shall, without prejudice to its powers to award compensation in respect of material or nonmaterial damage, have the power to grant relief by means of injunction or declaratory orders.

Head 91(4)(b) requires a plaintiff in a data protection action to specify, inter alia, 'any material or non-material damage alleged to have been occasioned by the infringement'.

The reference in Head 91(3) to the provision of other remedies 'without prejudice to [the Circuit Court's] ... powers to award compensation' assumes that the Court has such powers. In addition, the reference in Head 91(4)(b) to 'any material or nonmaterial damage' further assumes that that the powers to award compensation cover both material and non-material damage. However, these are simply assumptions; Head 91 does not expressly afford a claim compensation for material or non-material damage, nor is it expressly afforded elsewhere in the Scheme. It may be that this Head is predicated on the assumption that Article 82(1) GDPR provides those 'powers to award compensation'. Indeed, such an assumption seems to underpin the reference, in the explanatory note to Head 91, to a data subject seeking 'compensation for material or non-material damage under Article 82 of the Regulation ...' ${ }^{128}$ However, for the various reasons set out in Part 2, above, it is

\footnotetext{
${ }^{126}$ The full texts of Articles 79 and 82 GDPR are set out in $\S 4$ of Appendix I.

${ }^{127}$ The full text of Head 91 of the Scheme is set out in $\$ 1$ of Appendix II.

${ }^{128}$ The same assumption probably underpins the explanatory note to Head 24 of the Scheme (on data processing and freedom of expression and information), which comments that Article 82(1) GDPR 'clarifies that damages are payable in the case of data breaches giving rise to non-material damage'. Given the absence of an explicit claim
} 
ambiguous whether Article 82(1) GDPR does indeed provide the powers assumed by Head 91. Whilst that Head provides a framework for an effective judicial remedy for infringement of the GDPR or of its incorporating legislation, and whilst it assumes a claim for compensation, it does not expressly provide one. However, rather than hope that litigation to the CJEU requires that Article 82(1) GDPR be interpreted expansively, the best solution would be for Head 91 of the Scheme to contain an express provision incorporating Article 82(1) GDPR into Irish law.

\subsubsection{Articles 54 and 56 PCJAD, and Head 58 of the Scheme}

The structure of the PCJAD in this respect is very similar to that of the GDPR. Article 54 PCJAD provides for a right to an effective judicial remedy ${ }^{129}$ against a controller or processor, and Article 56 PCJAD provides for a claim for compensation as part of that effective judicial remedy. Head 58 of the Scheme seems to be directed towards these Articles. ${ }^{130}$ It provides that a person 'who suffers material or non-material damage' by reason of an infringement of the Part of the Scheme implementing the PCJAD 'shall have the right to receive compensation ...'. It is unfortunate that a similar clause was not provided in Head $91 .{ }^{131}$ However, Head 58 does not locate this claim for compensation in a framework for an effective judicial remedy for infringement of that Part of the Scheme, comparable with the framework provided in Head 91. It may be that Head 58 is predicated on the assumption that ordinary court procedures will fill that gap. However, rather than hope that litigation will work this issue out, the best solution would be for the claim for compensation in Head 58 of the Scheme to be contained in an express framework for an effective judicial remedy, much as is provided in Head 91.

\subsubsection{Heads 58 and 91 of the Scheme - Establishing a Common Framework} Both Head 58 and Head 91 do half the necessary work, and each does a different half: whereas Head 58 contains an express claim for compensation but does not provide a framework for an effective remedy, Head 91 provides a framework for an effective remedy but does not contain an express claim for compensation. The solution is simple: in Head 58 , add a framework for an effective remedy along the lines of that already provided in Head 91; and, in Head 91, add an express claim for compensation, following the lead of Head $58 .{ }^{132}$ In this way, the issues of compensation and remedies for infringement of the GDPR and the PCJAD will follow a common framework, and will be dealt with on a consistent basis in the Scheme.

\footnotetext{
for compensation in SI No 273 of 2007, a similar assumption seems to have been made in respect of Article 94 of the Plant Variety Rights Regulation (ns 20 and 46).

${ }^{129}$ The full text of Article 54 PCJAD is set out in $§ 5$ of Appendix I.

${ }^{130}$ The full text of Head 58 of the Scheme is set out in $\S 1$ of Appendix II.

${ }^{131}$ Similar, but not the same; see §3.4.2.

132 This solution is discussed further in $\S 3.4 .2$, and given effect in $\S \S 2$ and 3 of Appendix II.
} 


\subsubsection{Articles 21 and 22 pePR}

Finally, here, the structure of the pePR in this respect is also very similar to the GDPR and the PCJAD. Article 21 pePR provides for a right to an effective judicial remedy ${ }^{133}$ against a controller or processor; and Article 22 pePR provides for a claim for compensation as part of that effective judicial remedy. If these clauses remain in the Regulation as adopted, then legislation incorporating the pePR should deal with issues of compensation and remedies on the basis of the common framework recommended here for Heads 58 and 91 of the Scheme.

\subsubsection{Effective Remedies}

These various Heads will provide the means by which those who have suffered damage as a result of an infringement of the GDPR, the PCJAD, or the pePR, can have an effective judicial remedy, pursuant to Article 47 CFR, to vindicate their rights under those instruments. And they will also provide the means by which the State can meet its obligation, pursuant to Article 19 TEU, to provide remedies sufficient to ensure the effective legal protection of those rights. It is imperative, therefore, that the drafting of those Heads is as accurate and complete as possible. In this respect, the mistakes of the past are best avoided, and the lessons of history ${ }^{134}$ ought to be applied to the process of redrafting Heads 58 and 91 of the Scheme.

\subsection{Implementing the Data Protection Directive and the ePrivacy Directive}

\subsubsection{Avoiding the Mistakes of the Past}

In working out the detail of the common framework recommended here for Heads 58 and 91 of the Scheme, and for the incorporation of Articles 21 and 22 pePR, much can be learned from the existing implementations of the Data Protection Directive ${ }^{135}$ and the ePrivacy Directive ${ }^{136}$ into Irish and UK law. In particular, whilst some

\footnotetext{
${ }^{133}$ The full text of Article 21 pePR is set out in $\$ 6$ of Appendix I.

${ }^{134}$ George Santayana, The Life of Reason: Reason in Common Sense (Scribner 1905) 284 ('Those who cannot remember the past are condemned to repeat it'); Edmund Burke, Reflections on the Revolution France (Dodsley 1790) 47 ('People will not look forward to posterity, who never look backward to their ancestors').

${ }^{135}$ Directive 95/46/EC of the European Parliament and of the Council of 24 October 1995 on the protection of individuals with regard to the processing of personal data and on the free movement of such data (1995 OJ L 281) [the Data Protection Directive; hereafter DPD].

${ }^{136}$ Directive 2002/58/EC of the European Parliament and of the Council of 12 July 2002 concerning the processing of personal data and the protection of privacy in the electronic communications sector (2002 OJ L 201) [hereafter ePD]; as amended by Directive 2006/24/EC of the European Parliament and of the Council of 15 March 2006 on the retention of data generated or processed in connection with the provision of publicly available electronic communications services or of public communications networks and amending Directive 2002/58/EC (2006 OJ L 105); and as further amended by Directive 2009/136/EC of the European Parliament and of the Council of 25 November 2009 amending Directive 2002/22/EC on universal service and users' rights relating to electronic communications networks and services, Directive 2002/58/EC concerning the processing of personal data and the protection of privacy in the electronic communications sector and Regulation (EC) No 2006/2004 on cooperation between national authorities responsible for the enforcement of consumer protection laws (2009 OJ L 337) [cumulatively, hereafter the ePD (as amended)]; see §3.3.3.
} 
elements of those implementations may be worth replicating, one serious error must be avoided.

\subsubsection{Article 23 DPD after Collins v FBD and Google v Vidal-Hall}

Until the Scheme is enacted, the availability of damages for data subjects whose data protection rights have been infringed is governed by Article 23 DPD, implemented into Irish law by s 7 of the Data Protection Act, 1988 and into UK law by $s 13$ of the Data Protection Act $1998 .{ }^{137}$ Article 23 DPD provides:

Member States shall provide that any person who has suffered damage as a result of an unlawful processing operation or of any act incompatible with the national provisions adopted pursuant to this Directive is entitled to receive compensation from the controller for the damage suffered. ${ }^{138}$

In an object lesson in how not to give effect to an EU claim for compensation in national law, s 7 DPA 1988 provides:

For the purposes of the law of torts and to the extent that that law does not so provide, a person, being a data controller or a data processor, shall, so far as regards the collection by him of personal data or information intended for inclusion in such data or his dealing with such data, owe a duty of care to the data subject concerned ... ${ }^{139}$

\footnotetext{
${ }^{137}$ The (Irish) Data Protection Act 1988 is, hereafter, the DPA 1988; see also the Data Protection (Amendment) Act 2003. The (UK) Data Protection Act 1998 is, hereafter, the DPA 1998.

${ }^{138}$ The full text of Article 23 DPD is set out in $\S 7$ of Appendix I. It is worth noting that, whilst Article 23 DPD provides for liability only of controllers, Article 82(1) GDPR provides for liability of both controllers and processors.

Moreover, by way of contrast with the comparative linguistic analysis in ns 75 to 80 and Appendix III, and for what it is worth, all of the 23 language texts of Article 23(1) DPD are in the present tense. Of these, eight are unchanged in Article 82(1) GDPR (Bulgarian, Danish, French, Finnish, Hungarian, Latvian, Lithuanian, and Romanian); six are very similar (Czech, Estonian, Croatian, Italian, Dutch, and Portuguese); and five are different, but still in the present tense (German, Greek, Polish, Slovak, and Slovenian). Of the five contingent 'shall's in Article 82(1) GDPR, four (English, Maltese, Spanish, and Swedish) have changed from the present tense in Article 23(1) DPD; the Irish text is new.

There are only 23 language texts of the DPD, and not 24 , because there is no Irish language text. Irish did not become an official language of the EU into which legislation is translated until 1 January 2007; see Council Regulation (EC) No 920/2005 of 13 June 2005 amending Regulation No 1 of 15 April 1958 determining the language to be used by the European Economic Community and Regulation No 1 of 15 April 1958 determining the language to be used by the European Atomic Energy Community and introducing temporary derogation measures from those Regulations (2005 OJ L 156). Article 2 of that Regulation provides a derogation from the obligation to draft all official EU acts in Irish; and that derogation was renewed most recently (and probably for the last time) by Council Regulation (EU, Euratom) 2015/2264 of 3 December 2015 extending and phasing out the temporary derogation measures from Regulation No 1 of 15 April 1958 determining the languages to be used by the European Economic Community and Regulation No 1 of 15 April 1958 determining the languages to be used by the European Atomic Energy Community introduced by Regulation (EC) No 920/2005 (2015 OJ L 322).

${ }^{139}$ It is worth noting that, whilst Article 23 DPD provides for liability only of controllers (n 138), s 7 DPA (like Article 82(1) GDPR) provides for liability of both controllers and processors.
} 
In Collins V FBD Insurance plc, ${ }^{140}$ Feeney J gave this section an extremely narrow reading. ${ }^{141} \mathrm{He}$ held that it required plaintiffs to 'prove that they have, in fact, suffered damage arising from a breach ${ }^{142}$; and he further held that this requirement for actual damage precluded claims for non-pecuniary loss such as distress, and pain and suffering. ${ }^{143}$ As a consequence, he reversed the decision of the Circuit Court awarding the plaintiff general damages of $€ 15,000$. Moreover, this decision was uncritically referred to by Hogan $\mathrm{J}$ in the Court of Appeal in McCann v JM. ${ }^{144}$

Feeney J's narrow approach to s 7 DPA 1988 is wrong in principle: it discourages claims under that section, reduces private enforcement of data protection rights, and undermines the effectiveness of the data protection regime. Moreover, his reasoning is wrong as a matter of national law: he conflated general damages for distress with strict liability, overlooking that distress can amount to actual damage for which ordinary compensatory damages are uncontroversially available. ${ }^{145}$ Furthermore, the result in Collins is wrong as a matter of European law, not least

\footnotetext{
${ }^{140}$ [2013] IEHC 137 (14 March 2013); see Kelleher, ch 17; Gary Fitzgerald, 'Enforcement of Data Protection Rights post-Schrems' (Data Protection Update Conference, Ashville Media Group, Dublin, 26 May 2016); Andrea Mulligan, 'Actions for Damages in Data Protection Law' (Irish Rule of Law International Commercial Law Update, Dublin, 27 May 2017); see also my blog-posts at 'Full Breach Damages in Data Protection Cases - The Impact of Vidal-Hall on Collins v FBD' (13 June 2015) <http://www.cearta.ie/2015/06/full-breach-damages-in-dataprotection-cases-the-impact-of-vidal-hall-on-collins-v-fbd>. and 'Damages for Infringement of Data Protection Rights' (1 July 2016) <http://www.cearta.ie/2016/07/damages-for-infringement-of-data-protection-rights>.

${ }^{141}$ The section also played an important cameo in $K$ (A Minor) $v$ Independent Star [2010] IEHC 500 (3 November 2010), where Hedigan J held that s 7(1) of the Criminal Law (Rape) Act 1981, affording anonymity to complainants in sexual assault cases, did not give rise to a claim in damages for breach of statutory duty, as there was nothing like s 7 DPA 1988 to show that the legislature intended that the plaintiff would be entitled to make a claim for damages in such circumstances.
}

142 [2013] IEHC 137 [3.6].

${ }^{143}$ In the US, claims for damages for invasion of privacy against government agencies pursuant to $s 552$ (a) of the Privacy Act 1974 (5 USC § 552a) must demonstrate 'actual damages'; and the Supreme Court has held that distress is insufficient to amount to 'actual damages' for these purposes; see Doe v Chao 540 US 614 (2004); Federal Aviation Administration v Cooper 566 US 284 (2012). On the other hand, in Spokeo v Robins 578 US (2016), the Court held that an allegation of a bare procedural violation of the Fair Credit Reporting Act 1970 (15 USC $\S 1681$ ) was insufficient to establish injury in fact for the purposes of standing to bring a case in federal court pursuant to Article III of the US Constitution, but that intangible harms (such as anxiety or distress) could in principle constitute injury in fact for those purposes. See Daniel Solove and Danielle Citron, 'Risk and Anxiety: A Theory of Data Breach Harms' 96 Texas Law Review (2017, forthcoming) especially parts II.B.2 and III.B; Margot Kaminski "Standing after Snowden: Lessons on Privacy Harm from National Security Surveillance Litigation" 66 DePaul Law Review (2017, forthcoming).

144 [2015] IECA 281 (8 December 2015) [38] (Hogan J; Ryan P and Finlay Geoghegan J concurring).

${ }^{145}$ Contrast [2013] IEHC 137 [3.6] with Conway v Irish National Teachers Organisation [1991] 2 IR 305, 317 (Finlay $\mathrm{CJ}$ ) ('ordinary compensatory damages ... to recompense a wronged plaintiff for ... mental distress, anxiety, deprivation of convenience ...'); Shortt v Commissioner of an Garda Síochána [2007] 4 IR 587, 610-12 [2007] IESC 9 (21 March 2007) [77]-[83] (Murray CJ), [2007] 4 IR 587, 647, 652 [2007] IESC 9 [221], [231] (Hardiman J) (Denham J concurred with Murray CJ; Geoghegan and Fennelly JJ concurred with both Murray CJ and Hardiman J); Leech v Independent Newspapers [2015] 2 IR 214, 269 [2014] IESC 79 (19 December 2014) [128] (Dunne J; Murray J concurring). As to why Feeney J's misconceived reference to strict liability would not, in any event, have precluded a claim to general damages for distress on foot of EU law, see $n 173$. 
because Feeney J entirely failed to engage with the terms of Article 23 DPD at all. ${ }^{146}$ By contrast, the Court of Appeal in Google Inc v Vidal-Hall ${ }^{147}$ conducted a thorough analysis of the issue whether the obligation to provide compensation for damage in Article 23 DPD includes non-pecuniary loss, such as damages for distress, and concluded that it does. ${ }^{148}$ At issue was s 13 DPA $1998,{ }^{149}$ which provides:

(1) An individual who suffers damage by reason of any contravention by a data controller of any of the requirements of this Act is entitled to compensation from the data controller for that damage.

(2) An individual who suffers distress by reason of any contravention by a data controller of any of the requirements of this Act is entitled to compensation from the data controller for that distress if

(a) the individual also suffers damage by reason of the contravention ...

In Vidal-Hall, the Court of Appeal - referring to Leitner ${ }^{150}$ - held that the claim for compensation in Article 23 DPD includes non-pecuniary loss including distress, ${ }^{151}$ and that, although the limitation on that claim in s 13(2)(a) DPA 1998 could not be given an interpretation in conformity with Article $23 \mathrm{DPD},{ }^{152}$ the right to an effective remedy in Article 47 CFR required that limitation to be disapplied. ${ }^{153}$ Consequently, damages for distress have subsequently awarded pursuant to s 13 DPA $1998 .^{154}$

\footnotetext{
${ }^{146}$ The entirety of his analysis of Article 23 DPD was to accept - without any argument, analysis, or justification whatsoever - a submission that it is limited to claims of actual damage ([2013] IEHC 137 [3.6]), but he went on to overlook that distress can amount to actual damages (see previous note).

${ }^{147}$ [2016] QB 1003, [2015] EWCA Civ 311 (27 March 2015).

${ }^{148}$ In the process, the Court of Appeal felt unable to place much weight on Feeney J's judgment in Collins, as it did not address any of the reasoning which led them to conclude that 'damage' in Article 23 DPD includes nonpecuniary loss including distress ([2016] QB 1003, 1035, [2015] EWCA Civ 311 [71] (Lord Dyson MR and Sharpe L).

${ }^{149}$ See, generally, Jonathan Barnes in Nicole Moreham and Mark Warby (eds), Tugendhat and Christie on The Law of Privacy and the Media, 2nd edn (Oxford University Press 2016) 336-38 [7.92]-[7.99].

${ }^{150}$ See $\mathrm{n} 90$.

${ }^{151}$ [2016] QB 1003, 1035-38, [2015] EWCA Civ 311 [70]-[82] (Lord Dyson MR and Sharpe LJ, in a joint judgment; McFarlane LJ concurring).

${ }^{152}$ [2016] QB 1003, 1040-41, [2015] EWCA Civ 311 [91]-[94] (Lord Dyson MR and Sharpe L); on this interpretative obligation, see, eg, Case C-106/89 Marleasing SA v La Comercial Internacionale de Aliementacion SA [1990] ECR I-4135 [8]; Joined Cases C-397/01 to C-403/01 Pfeiffer v Deutsches Rotes Kreuz, Kreisverband Waldshut eV [2004] ECR I-8835 (ECLI:EU:C:2004:584; ECJ, 5 October 2004) [111]-[113]; P v Commissioner of Police of the Metropolis [2017] UKSC 65 (25 October 2017) [33] (Lord Reed; Lady Hale, Lord Kerr, Lord Wilson and Lord Hughes concurring); see also $n 156$.

${ }^{153}$ [2016] QB 1003, 1041-44, [2015] EWCA Civ 311 [95]-[105] (Lord Dyson MR and Sharpe L); on the impact of Article 47 CFR in the UK, see R (UNISON) v Lord Chancellor [2017] UKSC 51 (26 July 2017) [105]-[117] (Lord Reed; Lords Neuberger, Mance, Kerr, Wilson, and Hughes concurring) and $P v$ Commissioner (ibid) [28]; on Article 47 CFR generally, see notes $12,18,34-40,98-105$, and 120-22. On the supremacy of EU law and the consequent disapplication of domestic provisions incompatible with EU law, see Case 106/77 Amministrazione delle Finanze dello Stato v Simmenthal SpA [1978] ECR 629 (ECLI:EU:C:1978:49; ECJ, 9 March 1978); Case C-213/89 R v Secretary of State for Transport, ex parte Factortame Ltd [1990] ECR I-2433 (ECLI:EU:C:1990:257; ECJ, 19 June 1990), [1991] 1 AC 603; $R$ v Secretary of State for Transport, ex parte Factortame Ltd [2000] 1 AC 524, [1999] UKHL 44 (28 October 1999); Walker v Innospec Ltd
} 
By contrast, because Feeney J asserted a narrow view of Article 23 DPD, he was able to find that s 7 DPA 1988 was in conformity with it. ${ }^{155} \mathrm{Had}$ he taken instead an approach to Article 23 DPD consistent with Leitner and Vidal-Hall, then Collins would have been an easier case than Vidal-Hall: whereas the latter case required a disapplication of a statutory provision, Collins would simply have required an interpretation conforming with EU law. ${ }^{156}$ Furthermore, whilst Irish law of course acknowledges the duty to disapply a rule of national law which prevents a party from being able to enforce rights conferred by EU law, ${ }^{157}$ it is hard to see what parts of $\mathrm{s} 7$ DPA 1988 might be excised to leave a claim for damages for distress. ${ }^{158}$

Moreover, Collins is inconsistent, not only with Leitner and Vidal-Hall, but also with many other strands of the CJEU's damages jurisprudence. Where Feeney J took a narrow approach to compensation in the context of Article 23 DPD, the CJEU has taken the broad Sturgeon ${ }^{159}$ approach to compensation in a wide variety of contexts. ${ }^{160}$ Where Fenney J's decision negated the plaintiff's claim, the CJEU has

[2017] UKSC 47 (12 July 2017) [73]-[76] (Lord Kerr; Lady Hale and Lord Reed concurring), [78] (Lord Carnwarth and Lord Hughes); and see also $\mathrm{n} 157$.

${ }^{154}$ TLT v Secretary of State for the Home Department [2016] EWHC 2217 (QB) (24 June 2016) (Mitting J) (twelve awards ranging from Stf2,500 to $\mathrm{f12,500);} \mathrm{Brown} \mathrm{v} \mathrm{Commissioner} \mathrm{of} \mathrm{Police} \mathrm{of} \mathrm{the} \mathrm{Metropolis} \mathrm{(County} \mathrm{Court,}$ unreported, 7 October 2016, HHJ Luba QC) (Stf9,000); Woolley v Akram [2017] SC EDIN 7; [2017] ScotSC 7 (3 February 2017) (Sheriff Ross) (two awards of Stf8,634); Beyts v Trump International Golf Club Scotland Ltd [2017] SC EDIN 21, [2017] ScotSC 21 (5 April 2017) (Sheriff Ross) (no relevant breach on facts; had there been, damages would have been Stf750) [23]; Blamires v Local Government Ombudsman (County Court, unreported, 21 June 2017; District Judge Geddes) (Stf2,500; plus aggravated damages in the same amount).

155 [2013] IEHC 137 [3.3]-[4.4].

${ }^{156}$ On this interpretative obligation, see $\mathrm{n}$ 152. On the application of this obligation in Ireland, see, eg, Kelly $v$ UCD [2008] IEHC 464 (14 March 2008) [20] (McKechnie J); Eircom Ltd v Commission for Communications Regulations [2007] 1 IR 1, 24, [2006] IEHC 138 (29 July 2005) [35] (McKechnie J); Albatros Feeds v Minister for Agriculture and Food [2007] 1 IR 221, 243, [2006] IESC 52 (26 July 2006) (Fennelly J); JC Savage Supermarket Ltd v An Bord Pleanála [2011] IEHC 488 (22 November 2011) [3.8]-[3.11] (Charleton J); Environmental Protection Agency $v$ Harte Peat Ltd [2014] IEHC 308 (30 May 2014) [12]-[20] (Barrett J); Thompson v Dublin Bus [2015] IESC 22 (5 March 2015); Aldi Stores v Dunnes Stores [2016] IEHC 256 (15 March 2016) [74]-[76] (Cregan J); Smith v Meade [2016] IECA 389 (16 December 2016) [46]-[47] (Hogan J; Irvine and Hedigan JJ concurring). See, in particular, OCS One Complete Solution Ltd v Dublin Airport Authority plc [2014] IEHC 306 (30 May 2014) [5]-[13] (Barrett J) affd on this point [2015] IESC 6 (30 January 2015) [5.1]-[5.4] (Clarke J) (interpreting the implementations of the Public Sector Remedies Directive, as amended, and the Utilities Remedies Directive, as amended).

It may be that Irish courts find the limits of this obligation more quickly than their English counterparts; contrast EMI Records (Ireland) Ltd v UPC Communications Ireland Ltd [2010] IEHC 377 (11 October 2010) (Charleton J) with Cartier International AG v British Sky Broadcasting Ltd [2014] EWHC 3354 (Ch) (17 October 2014) (Arnold J) affd [2016] EWCA Civ 658 (6 July 2016). If so, then Collins stands as another example of such reticence.

${ }^{157}$ Dowling v Minister for Finance [2013] IESC 37 (31 July 2013) [10.5] (Clarke J; Denham CJ and Murray J concurring); see $\mathrm{n} 153$.

${ }^{158}$ If s 7 DPA 1988 were entirely disapplied, then a court could consider whether Article 23 DPD is directly effective; on which see text with and after $\mathrm{n} 225$.

${ }^{159}$ See $\mathrm{n} 84$.

${ }^{160}$ See $\S 2.5$. 
held that rights to compensation must not be rendered nugatory in practice. ${ }^{161}$ Furthermore, where Feeney J declined to award compensation for the plaintiff's full losses, the Marshall ${ }^{162}$ approach to compensation requires that losses be made good in full. ${ }^{163}$ Moreover, in Schrems, ${ }^{164}$ the CJEU emphasised that Article 47 CFR requires an effective remedy for breach of the rights to privacy and the protection of personal data in Articles 7 and $8 \mathrm{CFR}^{165}$; and if that effective remedy is to be given effect by means of Article 23 DPD and s 7 DPA 1988, then that section must be interpreted to reach damages for non-pecuniary loss. ${ }^{166}$ This conclusion is reinforced by the obligation on Member States, in Article 19 TEU, to provide 'remedies sufficient to ensure effective legal protection' in the fields covered by EU law ${ }^{167}$ : it is only by reading s 7 DPA 1988 in the light of Leitner, Sturgeon, Marshall and Schrems that the State's obligation to ensure effective legal protection in the field of data protection would be fully accomplished.

Indeed, in Commission v Portugal, ${ }^{168}$ Stadt Graz, ${ }^{169}$ Dekker, ${ }^{170}$ and Draehmpaehl, ${ }^{171}$ the ECJ held that claims for compensation for infringement of other Directives could not be made subject to a requirement of fault, ${ }^{172}$ and the similar requirement inherent in S 7's reference to a duty of care is likewise inconsistent with Article 23 DPD. Hence, even if Feeney $J$ had been correct that the claim for general damages for distress was an assertion of strict liability, ${ }^{173}$ these cases establish that such damages can, as a matter of EU law, be made available on that basis.

\footnotetext{
${ }^{161}$ Case C-536/11 Bundeswettbewerbsbehörde v Donau Chemie AG (ECLI:EU:C:2013:366; CJEU, 6 June 2013) [32] (competition damages). 
For these reasons, the decision of Feeney $\mathrm{J}$ in Collins is quite simply wrong - as a matter of principle, as a matter of national law, and as a matter of European law and the decision of the Court of Appeal in Vidal-Hall is to be preferred. A subsequent case might therefore seek to distinguish Collins, and provide an interpretation of $\mathrm{s} 7$ DPA 1988 conforming with Article 23 DPD. If that is not possible, ${ }^{174}$ a court could consider whether Article 23 DPD is directly effective. ${ }^{175}$ If it is not, then a plaintiff would have no remedy in damages for distress pursuant either to it or to 57 DPA 1988. In these circumstances, s 7 DPA 1988 would be an incomplete implementation of Article 23 DPD, and the State would be exposed to a potential claim for damages from someone who has suffered loss by virtue of the absence of a claim for nonmaterial damages from s $7 .{ }^{176}$ For example, in Dillenkofer, ${ }^{177}$ the CJEU held that Germany's failure to implement the original Package Holidays Directive gave rise to a claim for damages against Germany by holiday-makers who failed to get compensation and refunds for holidays where the organisers became insolvent.

Potentially even more catastrophic for the State would be an infringement action by the EU Commission ${ }^{178}$ against the State on the grounds that s 7 DPA 1988, as

\footnotetext{
${ }^{174}$ Perhaps for reasons of stare decisis or judicial comity: see, eg, Kearns v Manresa Estates Ltd (High Court, unreported, 25 July 1975, Kenny J); Irish Trust Bank Ltd v Central Bank of Ireland [1976] ILRM 50 (Parke J); In re Worldport Ireland Ltd [2005] IEHC 189 (16 June 2005) (Clarke J); Culkin v Sligo County Council [2015] IEHC 46 (6 February 2015) (Kearns P); Boyne v Dublin Bus/Bus Átha Cliath [2008] 1 IR 92, [2006] IEHC 209 (14 June 2006) (Gilligan J); ACC Loan Management Ltd v Connolly [2017] IECA 119 (4 April 2017) [25]-[26] (Hogan J); contrast Howard v Commissioners of Public Works [1994] 1 IR 101, 119 (Costello J).

${ }^{175}$ Case C-282/10 Dominguez v Centre Informatique du Centre Ouest Atlantique (ECLI:EU:C:2012:33; CJEU, 24 January 2012) [33]; Case C-671/13 'Indèliy ir investicijy draudimas' VJ v Guliavičius (ECLI:EU:C:2015:418; CJEU, 25 June 2015) [57].

${ }^{176}$ Joined Cases C-6/90 and C-9/90 Francovich and Bonifaci v Italy [1991] ECR I-5357 (ECLI:EU:C:1991:428; ECJ, 19 November 1991) [39]-[41]; Case C-46/93 Brasserie du Pêcheur v Germany [1996] ECR I-1029 (ECLI:EU:C:1996:79; ECJ, 5 March 1996) [55]-[56]; Case C-282/10 Dominguez v Centre Informatique du Centre Ouest Atlantique (ECLI:EU:C:2012:33; CJEU, 24 January 2012) [43]-[44]; Case C-244/13 Ogieriakhi v Minister for Justice and Equality [2014] ECR I-2068 (ECLI:EU:C:2014:2068; CJEU, 10 July 2014) [48]-[55]; Minister for Communications Marine and Natural Resources v Figary Water Sports Development Company Ltd [2015] IESC 74 (30 July 2015); Ogieriakhi v Minister for Justice and Equality [2017] IESC 52 (13 July 2017).

177 Joined Cases C-178/94, C-179/94, C-188/94, C-189/94 and C-190/94 Dillenkofer v Germany [1996] ECR I4845 (ECLI:EU:C:1996:375; ECJ, 8 October 1996); approved in Rooney $v$ Minister for Agriculture, Food and Forestry [2004] IEHC 305 (13 July 2004) (Laffoy J); affd [2010] IESC 55 (18 November 2010). See also Case C279/09 DEB Deutsche Energiehandels- und Beratungsgesellschaft $\mathrm{mbH} v$ Bundesrepublik Deutschland [2010] ECR I-13849 (ECLI:EU:C:2010:811; CJEU, 22 December 2010); Case C-441/14 Dansk Industri (DI) v Rasmussen (ECLI:EU:C:2016:278; CJEU, 19 April 2016) [42].

${ }^{178}$ Pursuant to Article 258 TFEU; see $n s 40$ and 231. A relatively recent, and quite spectacular, example relating to equality Directives considered in text with and in ns 56-65 and 91-98, is provided by Case C-286/12 Commission v Hungary (ECLI:EU:C:2012:687; CJEU, 6 November 2012), where the CJEU held that provisions of Hungarian law requiring the compulsory retirement of judges, prosecutors and notaries at the age of 62 infringed Articles 2 and 6(1) of the Employment Equality Directive.

In the most recent successful infringement action against Ireland (Case C-158/12 Commission v Ireland (ECLI:EU:C:2013:234; CJEU, 11 April 2013)) the CJEU found the State in breach of Directive 2008/1/EC of the European Parliament and of the Council of 15 January 2008 concerning integrated pollution prevention and control ( $2008 \mathrm{OJ} \mathrm{L} \mathrm{24)} \mathrm{by} \mathrm{failing} \mathrm{to} \mathrm{issue} \mathrm{or} \mathrm{update} \mathrm{permits} \mathrm{relating} \mathrm{to} \mathrm{pig-rearing} \mathrm{and} \mathrm{poultry-rearing}$ installations. In the most recent unsuccessful infringement action against Ireland (Case C-87/14 Commission v Ireland (ECLI:EU:C:2015:449; CJEU, 9 July 2015)) the CJEU dismissed the Commission's claim that Ireland had failed to fulfil its obligations under Directive 2003/88/EC of the European Parliament and of the Council of
} 
interpreted in Collins, amounts to an inaccurate or incomplete implementation of Article 23 DPD and thus to an infringement of the State's obligation, pursuant to Article 19 TEU, to provide 'remedies sufficient to ensure effective legal protection' in the field of data protection. As a consequence of the principle of sincere cooperation in Article 4(3) TEU, ${ }^{179}$ national courts are responsible for ensuring that EU law is applied and respected in the national legal systems. ${ }^{180}$ Where EU law is infringed by a national court, then the EU Commission can bring an infringement action before the CJEU to obtain a declaration that the Member State concerned has failed to fulfil its EU law obligations. ${ }^{181}$

For example, in Commission v Portugal, ${ }^{182}$ the ECJ held that, by failing to repeal legislation which made the right to damages pursuant to Public Sector Remedies Directive or the national laws implementing it, conditional on proof of fault or fraud, Portugal had failed to comply with the Court's earlier decision that such a right to damages could not be made conditional in that way. ${ }^{183}$ That earlier decision illustrates one of the many ways in which Collins is wrong, ${ }^{184}$ and the enforcement action illustrates the predicament in which the State may find itself as a consequence. However, given the imminence of the incorporation of the GDPR, an

4 November 2003 concerning certain aspects of the organisation of working time (2003 OJ L 299) by failing to apply the Directive to the organisation of the working time of non-consultant hospital doctors.

${ }^{179}$ Imelda Maher, 'National Courts as European Community Courts' (1994) 14(2) Legal Studies 226; John Temple Lang, 'The Development by the Court of Justice of the Duties of Cooperation of National Authorities and Community Institutions under Article 10 EC' (2008) 31(5) Fordham International Law Journal 1483; Nial Fennelly, 'The National Judge as Judge of the European Union' in Rosas, Levits \& Bot, 61; John Temple Lang, 'The Duty of Cooperation of National Courts in EU Competition Law' (2014) 17(1) Irish Journal of European Law 27; Urszula Jaremb, National Judges as EU Law Judges: The Polish Civil Law System (Martinus Nijhoff 2013) ch 2; Marcus Klamert, The Principle of Loyalty in EU Law (Oxford University Press 2014) ch 6.

${ }^{180}$ Case 14/83 von Colson v Land Nordrhein-Westfalen [1984] ECR 1891 (ECLI:EU:C:1984:153; ECJ, 10 April 1984) [26] (Article 5 EC); Case 80/86 Kolpinghuis Nijmegen BV [1987] ECR 3969 (ECLI:EU:C:1987:431; ECJ, 8 October 1987) [12]; Case C-2/88-Imm Zwartveld [1990] ECR I-3365 (ECLI:EU:C:1990:315; ECJ, 13 July 1990) [18] (sincere cooperation); Case C-2/88-Imm Zwartveld [1990] ECR I-4406 (ECLI:EU:C:1990:440; ECJ, 6 December 1990) [10]; Case C-234/89 Delimitis v Henninger Brau AG [1991] ECR I-935 (ECLI:EU:C:1991:91; ECJ, 28 February 1991) [53] (Article $5 \mathrm{EC)}$; Case C-94/00 Roquette Frères v Directeur général de la concurrence, de la consommation et de la répression des frauds [2002] ECR I-9011 (ECLI:EU:C:2002:603; ECJ, 22 October 2002) [30]-[31], [93] (Article 10 EC); Case C-339/00 Ireland v Commission [2003] ECR I-11757 (ECLI:EU:C:2003:545; ECJ, 16 October 2003) [71][72]; C-432/05 Unibet v Justitiekanslern [2007] ECR I-2271 (ECLI:EU:C:2007:163; ECJ, 13 March 2007) [37]-[38] (Article 47 CFR); Joined Cases C-200/07 and C-201/07 Marra $v$ de Gregorio and Clemente (ECLI:EU:C:2008:579; ECJ; 21 October 2008) [42] (Article 10 EC); Opinion 1/09 [2011] ECR I-1137 (ECLI:EU:C:2011:123; ECJ, 8 March 2011) on the European and Community Patents Court [66]-[69] (Article 4(3) TEU); C-583/11 P Inuit Tapiriit Kanatami v Parliament and Council (CLI:EU:C:2013:625; CJEU, 3 October 2013) [90], [98] (Article 19 TEU); Opinion 2/13 (ECLI:EU:C:2014:2454; CJEU, 18 December 2014) on the Accession of the EU to the ECHR [165], [174]-[177] (Article 19 TEU).

${ }^{181}$ Case C-129/00 Commission v Italy [2003] ECR I-14637 (ECLI:EU:C:2003:656; ECJ, 9 December 2003) [29]-[32]; Opinion 1/09 [2011] ECR I-1137 (ECLI:EU:C:2011:123; ECJ, 8 March 2011) on the European and Community Patents Court [87]; Maciej Taborowski, 'Infringement Proceedings and Non-Compliant National Courts' (2012) 49(6) Common Market Law Review 1881; Zsófia Varga, 'National Remedies in the Case of Violation of EU law by Member State Courts' (2017) 54(1) Common Market Law Review 51.

${ }^{182}$ Case C-70/06 Commission v Portugal [2008] ECR I-0001 (ECLI:EU:C:2008:3; ECJ, 10 January 2008).

${ }^{183}$ See ns 88 and 168.

${ }^{184}$ See ns 168-73. 
infringement action in respect of the Data Protection Directive is highly unlikely, but the threat remains.

\subsubsection{Article 15(2) ePD and the Potential Perverse Persistence of Collins}

In any event, if it is not formally overruled or otherwise departed from before the GDPR applies, Collins will not thereafter be good law in the Irish data protection context. However, even then, it may not be entirely irrelevant, as it could perversely - influence the interpretation of the Irish implementation of the ePrivacy Directive ${ }^{185}$ until the pePR is adopted by the EU and incorporated into Irish law. Article 15(2) ePD provides:

The provisions of Chapter III on judicial remedies, liability and sanctions of Directive $95 / 46 / E C\left[{ }^{186}\right]$ shall apply with regard to national provisions adopted pursuant to this Directive and with regard to the individual rights derived from this Directive. ${ }^{187}$

The ePD (as amended) is implemented into Irish law by the Privacy and Electronic Communications Regulations. ${ }^{188}$ In that context, by virtue of its terms, the implementation of Article 15(2) ePD could easily have referred to, or even reproduced, s 7 DPA 1988. Had that been so, Collins would have been directly relevant to the question of availability of damages for breach of the Irish provisions implementing the ePrivacy Directive. However, the PECR did not take that route. Instead, Regulation 16(2) PECR is much more straightforward; it simply provides:

A person who suffers loss and damage as a result of a contravention of any of the requirements of these Regulations by any other person shall be entitled to damages from that other person for that loss and damage. ${ }^{189}$

Taking its lead from Article 15(2) ePD's reference to the DPD, this text is not dissimilar to Article 23 DPD, and it is unfathomable why the implementation of that Article in s 7 DPA 1988 was not as straightforward the implementation of Article 15(2) ePD in Regulation 16(2) PECR. Had it been, the problems in Collins would never have arisen. In any event, Regulation 16(2) PECR will continue to be the basis of damages for infringement of those Regulations until the pePR is adopted by the EU and incorporated into Irish law. There have been no Irish cases on Regulation 16(2)

\footnotetext{
${ }^{185}$ See n 136.

${ }^{186}$ The Data Protection Directive; see $\mathrm{n} 135$.

${ }^{187}$ The full text of Article 15(2) ePD is also set out in $\S 8$ of Appendix I.

${ }^{188}$ European Communities (Electronic Communications Networks and Services) (Privacy and Electronic Communications) Regulations 2011 (SI No 336 of 2011) [the Privacy and Electronic Communications Regulations; hereafter PECR].

${ }^{189}$ This is exactly the same text as appeared in Regulation 16(1) of the European Communities (Electronic Communications Networks and Services) (Data Protection and Privacy) Regulations 2003 (SI No 535 of 2003), implementing the original text of Directive 2002/58/EC.
} 
PECR or its predecessor. ${ }^{190} \mathrm{~A}$ broadly equivalent statutory provision has been enacted in Canada, ${ }^{191}$ but it has not yet been commenced, ${ }^{192}$ and so provides no comparative guidance at present on questions of damages pursuant to Regulation 16(2) PECR. Nor should Collins. Notwithstanding the interlinkages between Article 15(2) ePD and Article 23 DPD, it would be perverse for Collins to have any impact at all on the interpretation and application of Regulation 16(2) PECR, because it is wrongly decided, as a matter of principle, as a matter of national law, and a matter of European law. Nevertheless, unless and until it is formally overruled or otherwise departed from, some unfortunate residual perverse effects of Collins - such as an interpretation of Regulation 16(2) PECR similar to Feeney J's interpretation of $s$ DPA 1988, perhaps even by analogy with Collins - cannot be entirely ruled out. ${ }^{193}$ And if this were to happen, then the prospect of an infringement action in respect of Collins will not have entirely receded. ${ }^{194}$ In any event, these effects should fall away when Article 15(2) ePD and Regulation 16(2) PECR are replaced by Article 22 pePR and its legislative incorporation.

\subsection{Applying the Lessons of History}

\subsubsection{Four Lessons in Drafting}

Four important lessons can be learned from the implementation of Article 23 DPD by S 7 DPA 1988, and of the implementation of Article 15(2) ePD by Regulation 16(2) PECR. These lessons can be applied to the incorporation of 82(1) GDPR in Head 91 of the Scheme, to the implementation of Article 56 PCJAD in Head 58 of the Scheme, and to any future legislative provision incorporating Article 22 pePR.

\footnotetext{
${ }^{190}$ There is only a passing reference to the PECR in EMI Records (Ireland) Ltd v Data Protection Commissioner [2012] IEHC 264 (27 June 2012) [8.3] (Charleton J) affd [2013] IESC 34 (03 July 2013) [2.6] (Clarke J; Fennelly and O'Donnell JJ concurring). In Microsoft Corporation v McDonald [2006] EWHC 3410 (Ch) (12 December 2006) Lewison J held that, pursuant to the UK's implementation of the ePD in the Privacy and Electronic Communications (EC Directive) Regulations 2003 (SI No 2426 of 2003), Microsoft were entitled to compensation from a spammer pursuant to Regulation 30 of the 2003 Regulations; see also Lebara Mobile Ltd v Lycamobile UK Ltd [2015] EWHC 3318 (Ch) (17 November 2015) [104]-[108] (Deputy Judge Lavender QC). For background on the issue in Lebara, see Steve Hedley, 'A Brief History of Spam' (2006) 15(3) Information \& Communications Technology Law 223, 230-31.

${ }^{191}$ See $\mathrm{s} 51$ of the Act to promote the efficiency and adaptability of the Canadian economy by regulating certain activities that discourage reliance on electronic means of carrying out commercial activities, and to amend the Canadian Radio-television and Telecommunications Commission Act, the Competition Act, the Personal Information Protection and Electronic Documents Act and the Telecommunications Act 2010 [Canada's AntiSpam Legislation; hereafter CASL]. For background on the issues that led to the CASL, see Éloise Grattan, 'Dealing with Unsolicited Commercial Emails: A Global Perspective' (2004) 6 Journal of Internet Law 3.

${ }^{192}$ Para (c) of the Order Fixing Certain Dates as the Days on which Certain Provisions of the Act Come into Force 2013 (SI No 127 of 2013) (PC 2013-1323 of 3 December 2013) set 1 July 2017 as the CASL's commencement date. However, para (c) was repealed by Order Amending Order in Council PC 2013-1323 of 3 December 2013 in order to delay the Coming into Force date of ss 47-51 and 55 of Canada's Anti-spam Law, which provides for a private right of action, in order to promote legal certainty for numerous stakeholders claiming to experience difficulties in interpreting several provisions of the Act while being exposed to litigation risk (PC 2017-0580 of 2 June 2017).

${ }^{193}$ See K (A Minor) v Independent Star (n 141) and McCann v JM (n 144).

${ }^{194}$ See ns $178-84$.
} 


\subsubsection{Lesson 1: Don't Follow s 7 DPA 1988}

The first lesson that can be drawn from existing implementations is that future incorporations and implementations should not follow the baleful lead of s 7 DPA 1988 as interpreted in Collins, ${ }^{195}$ but should instead commence with as much of the language of the relevant Article of the relevant Regulation or Directive as possible. Indeed, Recital 8 GDPR encourages as much, by permitting the incorporation of 'elements' of the Regulation. It is neither necessary nor desirable to reinvent the wheel, and Collins illustrates the dangers of trying to do so.

However, in this context, two linguistic decisions will have to be made. One is whether the incorporating legislation should replicate the problematic contingent 'shall have the right to receive compensation' in the English version of Article 82(1) GDPR or should instead employ a simpler present tense like the literal English translations of the French or German versions of Article 82(1) ('has the right to obtain compensation' or 'is entitled to compensation'). The most appropriate wording for expressing a right or entitlement is that the plaintiff 'is entitled to' it. ${ }^{196}$ This is simple and unambiguous, and for that reason should be used in national incorporations of Article 82(1) GDPR. For the same reason, other potentially ambiguous 'shall's should also be avoided in those incorporations. ${ }^{197}$

The other linguistic decision is whether the legislation should follow the lead of Article 82(1) and refer to 'compensation' for breach, or whether it should follow normal Irish practice and refer to 'damages'. Here, Regulation 16(2) PECR shows the way, whereas Article 15(2) ePD refers to Article 23 DPD which refers to 'compensation', the implementation of Article 15(2) ePD in Regulation 16(2) PECR refers to 'damages'. Similarly, in giving effect to Article 1 of the Products Liability Directive, s 2(1) of the Liability for Defective Products Act, 1991 characterised the claim as one for 'damages'. Given that 'compensation' in EU terms can be taken to mean 'damages' in Irish terms, incorporating or implementing legislation should refer to 'damages' where the relevant Regulations or Directives refer to 'compensation'. ${ }^{198}$ Nothing will be lost in incorporation or implementation, and accuracy of analysis at Irish law will be gained.

\footnotetext{
${ }^{195}$ The uncritical reference to the inferior s 7 DPA 1988 in the explanatory notes to Head 58 of the Scheme is, to say the least, unfortunate.

${ }^{196}$ Garner, 954-55.

${ }^{197}$ See $\S 2.4$; see also n 213.

${ }^{198}$ Indeed, the various languages set out in Appendix III use many synonyms for compensation which could literally have been rendered in English variously as amends, damages (esp: DE 'Schadenersatz'), indemnity (esp: ET 'hüvitist'), indemnification (esp: ES 'indemnización'; PT 'indemnização'), recompense, redress, reimbursement, reparation (esp: FR 'réparation'; RO 'despăgubiri'), repayment, replacement (esp: CS 'náhradu'; SK 'náhradu'; SV 'ersättning'), restitution, or satisfaction. However, for simplicity, they are all translated as 'compensation' in Appendix III. After all, 'What's in a name?' Romeo and Juliet (n 1, line 45, 189).
} 
Head 91 of the Scheme begins, but does not complete, the process of incorporating Articles 79 and 82 GDPR into Irish law. In particular, while it provides a framework for an effective judicial remedy for infringement of the GDPR or of its incorporating legislation, it does not contain an express claim for compensation. ${ }^{199}$ It should therefore be amended to include a new subsection using as much of the language of Article 82(1) GDPR as possible, modified as set out in the previous paragraph. ${ }^{200}$

Similarly, Head 58 of the Scheme begins, but does not complete, the process of implementing Articles 54 and 56 PCJAD into Irish law. In particular, while it contains an express claim for compensation, it does not provide a framework for an effective judicial remedy for infringement of the Part of the Scheme implementing the PCJAD. ${ }^{201}$ The claim for compensation in Head 58 could be improved if it cleaved even more closely to the language of Article 56 PCJAD - and, for the reasons set out above, this should be modified to refer to damages rather than compensation. ${ }^{202}$ Moreover, that Head should be further amended to locate this claim for damages in the context of a framework for an effective judicial remedy, comparable with the framework provided in Head $91 .{ }^{203}$

Similar considerations should apply in respect of Article 22 pePR. For the same reasons that Article 82(1) GDPR should be incorporated into Irish law by an express statutory claim for damages, so also should Article 22 pePR be. The incorporating subsection, in the first instance, should be modelled as much as possible on Article 22 pePR itself. The text of that subsection should then be modified to refer to 'damages' rather than 'compensation', and to avoid the potentially ambiguous 'shall'. Finally, that subsection should be placed in the context of a framework for an effective judicial remedy, along the lines of Head 91 of the Scheme. ${ }^{204}$

\subsubsection{Lesson 2: Prescribe that Courts Make the Awards of Damages}

The second lesson that can be drawn from existing implementations is that future incorporations and implementations will have to prescribe who gets to make the awards of damages. For example, statutory provisions similar to Article 82 GDPR in other jurisdictions demonstrate that a claim for compensation or damages can be given effect by means of a determination by a data protection authority or tribunal, ${ }^{205}$ or by a decision of a court, ${ }^{206}$ or both. ${ }^{207}$ The right to an effective remedy

\footnotetext{
${ }^{199}$ See $§ 3.2 .1$.

${ }^{200}$ See the draft of Head 91(2) in $\S \S 2$ and 3 of Appendix II.

${ }^{201}$ See §3.2.2.

${ }^{202}$ See the draft of Head 58(2) in $\S \S 2$ and 3 of Appendix II.

${ }^{203}$ See the draft of Head 58(1), (3)-(6) ibid.

${ }^{204}$ See $\S 4$ of Appendix II.

${ }^{205}$ As in New Zealand; see s 88 of the Privacy Act 1993; see Katrine Evans, 'The Rise and Rise of Damages Awards for Breaches of Privacy? Hamilton v The Deanery 2000 Ltd' (2003) 10(7) Privacy Law and Policy Reporter 127;
} 
in Article 47 CFR, Article 79 GDPR, Article 54 PCJAD, and Article 21 pePR, requires a court or tribunal. ${ }^{208}$ The current Irish position leaves issues of private enforcement such as claims for damages to the courts, whilst the role of the Office of the Data Protection Commissioner is one of public regulation and enforcement. The Scheme incorporating the GDPR does not suggest any change to this balance. In particular, the revamped Data Protection Commission is afforded enhanced public regulation and enforcement functions, but is given no role in private enforcement. Instead, alongside the Commission's public functions, Head 91 envisages private enforcement by means of 'a "parallel" avenue of redress through the courts" ${ }^{209}$ for claims for breach of the GDPR. Likewise, Head 58 provides equivalent parallel redress and private enforcement for breaches of the PCJAD.

Similar considerations will have to apply in respect of Article 22 pePR. Since the incorporated GDPR claim for damages will be a matter of private enforcement for the Irish courts rather than the revamped Data Protection Commission, then, because the enforcement mechanisms of the GDPR are adopted by the pePR, ${ }^{210}$ the incorporated claim for damages for infringement of the pePR at Irish law will also have to be a matter of private enforcement for the courts. For the avoidance of doubt, this should be expressly clarified in any legislation incorporating the pePR into Irish law.

\subsubsection{Lesson 3: 'an action founded on tort'}

The third lesson that can be drawn from existing implementations is that future incorporations and implementations will have to clarify the nature of the damages claim at national law. For example, in giving effect to Article 1 of the Products Liability Directive, s 2(1) of the Liability for Defective Products Act 1991 characterised

Katrine Evans, 'Show Me the Money: Remedies under the Privacy Act' (2005) 36 Victoria University of Wellington Law Review 475.

${ }^{206}$ As in Canada; see s 16(c) of the Personal Information Protection and Electronic Documents Act 2000; Sidney Elbaz and Éloise Gratton, 'What Damages Can Be Claimed Pursuant to the PIPEDA by the Victims of Breach of Privacy' (2011) 8(3) Canadian Privacy Law Review 25; David Elder, 'Panning for Gold in the Mud: The Availability of Privacy Damages under PIPEDA' (2011) 9(1) Canadian Privacy Law Review 6; Neil Wilson, 'Damages under PIPEDA: A Purposive Approach and a New High Water Mark' (2013) 11(1) Canadian Privacy Law Review 1.

${ }^{207}$ As in Australia; see s 25 of the Privacy Act 1988 (Cth) (Court); s 52 (ibid) (Information Commissioner).

${ }^{208}$ On the features of a court or tribunal as defined by EU law, see, eg, Case C-53/03 Synetairismos Farmakopoion Aitolias v GlaxoSmithKline plc [2005] ECR I-4609 (ECLI:EU:C:2005:333; ECJ, 31 May 2005) [29]; Case C-506/04 Wilson v Ordre des avocats du barreau de Luxembourg [2006] ECR I-8613 (ECLI:EU:C:2006:587; ECJ, 19 September 2006) [47]-[53]; Case C-175/11 HID v Refugee Applications Commissioner (ECLI:EU:C:2013:45; CJEU, 31 January 2013) [95]-[97]; Case C-394/11 Valeri Hariev Belov v CHEZ Elektro Balgaria AD (ECLI:EU:C:2013:48; CJEU, 31 January 2013) [40]; Joined Cases C-58/13 and C-59/13 Torresi v Consiglio dell'Ordine degli Avvocati di Macerata (ECLI:EU:C:2014:2088; CJEU, 17 July 2014) [16]-[19]; Case C-222/13, TDC A/S v Erhvervsstyrelsen (ECLI:EU:C:2014:2265; CJEU, 9 October 2014) [27]-[32]; Case C-203/14 Consorci Sanitari del Maresme v Corporació de Salut del Maresme i la Selva (ECLI:EU:C:2015:664; CJEU, 06 October 2015) [17][30].

${ }^{209}$ Explanatory notes to Head 91 of the Scheme.

${ }^{210}$ See ns 28-30. 
the claim as one for damages 'in tort' ${ }^{211}$ Again, the Sea Pollution (Hazardous Substances) (Compensation) Act 2005 gives effect to the International Convention on Liability and Compensation for Damage in connection with the Carriage of Hazardous and Noxious Substances by Sea 1996. Section 16(1) of that Act provides:

An action for compensation under the Convention ... shall be deemed for the purposes of every enactment and rule of law to be an action founded on tort. $^{212}$

If a provision equivalent to $\mathrm{s} 16(1)$, amended to come into line with the avoidance of potentially ambiguous 'shall's, ${ }^{213}$ were included in the incorporation of Articles 79 and 82 GDPR in Head 91 of the Scheme, and in the implementation of Articles 54 and 56 PCJAD in Head 58 of the Scheme, then fundamental issues such as causation, remoteness, measures of damages (including disgorgement, and aggravated, and exemplary or punitive, damages), mitigation, limitation, contributory negligence, vicarious liability, defences, damages jurisdictions in the various courts, and so on, ${ }^{214}$ could be resolved by the application of settled principles of tort law. In this way, there would be two consequences for the substantive and procedural conditions on claims for damages laid down by national law in Heads 58 and 91 of the Scheme, in respect of claims for damages for infringement of the Part of the Scheme implementing the PCJAD, and in respect of claims for damages for infringement of the GDPR and its incorporation in the Scheme. As a consequence, the damages claims in Heads 58 and 91 would be equivalent to, and thus not less favourable than, those relating to similar domestic claims; and they would be effective and thus not virtually impossible or excessively difficult to employ. ${ }^{215}$

\footnotetext{
${ }^{211}$ On the nature of that tort claim, compare Leo Laboratories v Crompton BV [2005] 2 IR 225, [2005] 2 ILRM 423, [2005] IESC 31 (12 May 2005) with Case C-45/13 Kainz v Pantherwerke AG (ECLI:EU:C:2014:7; CJEU, 16 January 2014).

${ }^{212}$ s 28 of the Merchant Shipping (Liability of Shipowners and Others) Act 1996 is to similar effect. See also s 32(6) of the Competition Act 2002 and s 32(7) of the Consumer Protection Act 2007, unaccountably not reenacted in s 25 of the Competition and Consumer Protection Act 2014.

${ }^{213}$ See $\$ 2.4$; see also text with and in ns 196-97.

${ }^{214}$ References to fundamental issues are references to this non-exhaustive list; on these issues in the context of the GDPR, see Brendan Van Alsenoy, 'Liability under EU Data Protection Law: From Directive 95/46 to the General Data Protection Regulation' (2017) 8(1) Journal of Intellectual Property, Information Technology and ECommerce Law 271. On punitive damages in this context, compare $\mathrm{n} 97$.

${ }^{215}$ Compare Case 33-76 Rewe-Zentralfinanz eG v Landwirtschaftskammer für das Saarland [1976] ECR 01989 (ECLI:EU:C:1976:188; ECJ, 16 December 1976) [5]; Case 45-76 Comet BV v Produktschap voor Siergewassen [1976] ECR 02043 (ECLI:EU:C:1976:191; ECJ, 16 December 1976) [13]; Joined Cases C-6/90 and C-9/90 Francovich and Bonifaci $v$ Italy [1991] ECR I-5357 (ECLI:EU:C:1991:428; ECJ, 19 November 1991); BUPA Ireland Ltd v Health Insurance Authority [2013] IEHC 103 (07 March 2013) [106] (Cooke J); see also McNamara v An Bord Pleanála [1998] 3 IR 453 (SC); Arklow Holidays Ltd v An Bord Pleanála [2011] IESC 29 (21 July 2011); SHM v Minister for Justice and Equality [2015] IEHC 829 (21 December 2015); Student Transport Scheme Ltd v Minister for Education and Skills [2015] IECA 303 (18 December 2015) [32]-[33] (Hogan J; Ryan P and Peart J and concurring); Danqua v Minister for Justice and Equality (No 2) [2017] IECA 20 (6 February 2017).
} 
However, there is no provision equivalent to s 16(1) of the 2005 Act in Heads 58 or 91 of the Scheme, so many of these fundamental issues ${ }^{216}$ remain open. If Article 82(1) GDPR does create an unambiguous claim for compensation, then it is likely that the Irish courts would deal with such issues by analogy with tort, ${ }^{217}$ because of the obligation to interpret national law to give effect to European law, ${ }^{218}$ of the principles of equivalence and effectiveness, ${ }^{219}$ and of the combination of Article 47 CFR and Article 19 TEU. ${ }^{220}$ However, it would be better to have this matter settled by legislation rather than leaving it to the vagaries of litigation. Hence, it should be expressly provided that the claims in Heads 58 and 91 are actions founded on tort. ${ }^{221}$ Furthermore, such an express reference to tort would reinforce the proposal above that the incorporating and implementing legislation should refer to 'damages' where Article 82(1) GDPR, and Article 56 PCJAD refer to 'compensation'.

Similar considerations should apply in respect of Article 22 pePR. Any incorporation of that Article should specify that it is an action founded on tort, so that many fundamental issues could be resolved by the application of settled principles of tort law.

\subsubsection{Lesson 4: Be as Complete as Possible}

The fourth lesson that can be drawn from existing implementations is that future incorporations and implementations will have to be as complete as possible. Part of the problem in Collins was just how laconic s 7 DPD 1988 is. For example, if a provision modelled on Article 82(1) GDPR is to be added to Head 91 of the Scheme, then other elements of Article 82 may also need be added. On the one hand, Article

\footnotetext{
${ }^{216}$ See $\mathrm{n} 214$.

${ }^{217}$ In Tate v Minister for Social Welfare [1995] 1 IR 418, [1995] 1 ILRM 507, in an action for damages arising out of the State's failure properly to incorporate Council Directive 79/7/EEC of 19 December 1978 on the progressive implementation of the principle of equal treatment for men and women in matters of social security, Carroll J held that the government's failure to observe European law in this respect amounted to a tort for the purposes of s 11(2)(a) of the Statute of Limitations 1957. Carroll J affirmed Tate in McDonnell v Ireland [1998] 1 IR 134, [1996] 2 ILRM 222 and Murphy $v$ Ireland [1996] 2 ILRM 461, and her judgment in McDonnell was upheld by the Supreme Court. See also Dekra Erin Teo v Minister for the Environment and Local Government [2002] 2 ILRM 30, [2001] IEHC 154 (2 November 2001) (O’Neill J) (Tate semble distinguished); Kenny v Minister for Agriculture and Food [2013] IEHC 520 (1 November 2013) (Laffoy J) (Tate semble applied).

With Tate, compare $R v$ Secretary of State for Transport, ex parte Factortame Ltd (No 7) [2001] 1 WLR 942, [2000] EWHC Technology 179 (27 November 2000) (HHJ Toulmin QC) [128]-[134] (Tate considered), [153], [170]-[179] (wide construction of 'action founded on tort' in s 2 of the Limitation Act 1980 catches claims against the government for breaches of European law). More generally, in Garden Cottage Foods Ltd v Milk Marketing Board [1984] AC 130, 141, Lord Diplock for a unanimous House of Lords held that there is no need to invent a new cause of action for a private law claim for damages for breach of European competition law, because the existing tort of breach of statutory duty plainly covered such claims. See also Sempra Metals Ltd v Her Majesty's Commissioners of Inland Revenue [2008] 1 AC 561, 595, [2007] UKHL 34 (18 July 2007) [69] (Lord Nicholls); Nuclear Decommissioning Authority v EnergySolutions EU Ltd [2017] 1 WLR 1373, 1394, [2017] UKSC 34 (11 April 2017) [38] (Lord Mance).

${ }^{218}$ See ns 133 and 137.

${ }^{219}$ See $\mathrm{n} 215$.

${ }^{220}$ See ns $37-38$ and 122.

${ }^{221}$ See the drafts of Heads 58(7) and 91(7) in §§2 and 3 of Appendix II.
} 
82(4) and (5) GDPR provide for concurrent, and joint and several, liability. If a provision is added to Head 91 providing that the data protection claim in that Head is an action founded on tort, then the provisions of Part III of the Civil Liability Act 1961 will deal with issues of concurrent, and joint and several, liability; and it will not be necessary to afford further incorporation to Article 82(4) and (5) GDPR. On the other hand, Article 82(2) and (3) provide for some defences to the claim for compensation in Article 82(1), and if the claim in Article 82(1) is added to Head 91, then the defences to the claim will have to be added to Head 91 as well. ${ }^{222}$

\subsubsection{Preventing a Tragedy from Becoming a Farce}

The conclusions that Head 58 is an incomplete implementation of Articles 54 and 56 PCJAD and that Head 91 is an incomplete incorporation of Articles 79 and 82 GDPR, and the practical necessity to ensure accurate and complete implementation and incorporation, are the driving forces behind the amendments to Heads 58 and 91 suggested here. If these Heads are indeed incomplete, and if the amendments suggested here (or something similar) are not made, so that Heads 58 and 91 (or something similar) make it into the legislation as ultimately enacted, then the Irish courts will be obliged to interpret the unamended or otherwise inaccurate or incomplete Heads 58 and 91 to conform with Articles 54 and 56 PCAJD or Articles 79 and 82 GDPR (respectively). ${ }^{223}$ However, there are limits to the extent to which the interpretative obligation can rescue an inaccurate or incomplete implementation or incorporation. For example, s 7 DPA 1988, as interpreted in Collins, is an inaccurate implementation of Article 23 DPD, which was not rescued by a conforming interpretation. $^{224}$

If an interpretation conforming with EU law cannot be given to Head 58, the question would then arise whether Article 56 PCJAD is directly effective, ${ }^{225}$ and the ambiguity $^{226}$ at its heart would tell against it. On the other hand, if a conforming interpretation cannot be given to Head 91, no question could arise as to whether Article 82(1) GDPR is directly effective, ${ }^{227}$ though this does not answer the ambiguity $^{228}$ at its heart.

If a conforming interpretation or direct effect cannot rescue Heads 58 and 91, then as in Dillenkofer ${ }^{229}$ - a person who has suffered loss by reason of the incomplete

\footnotetext{
${ }^{222}$ See the drafts of Heads 58(8) and 91(8) (ibid).

${ }^{223}$ See ns 152 and 156.

${ }^{224}$ See $\$ 3.2 .2$.

${ }^{225}$ See $n 175$.

${ }^{226}$ On this ambiguity, see $\S 2.4$.

${ }^{227}$ See $n$ 19. Similarly, no such question could arise with Article 22 pePR.

${ }^{228}$ On this ambiguity, see $\S 2.4$.

${ }^{229}$ See $n 177$.
} 
incorporation or implementation could seek damages from the State for such loss. ${ }^{230}$ Potentially even more catastrophic for the State would be an infringement action by the EU Commission ${ }^{231}$ against the State for an inaccurate or incomplete incorporation or implementation, an action that would be reinforced by the State's breach of its Article 19 TEU obligation to provide 'remedies sufficient to ensure effective legal protection' in the field of data protection.

Of course, the problems of inaccurate or incomplete implementation or incorporation are attendant upon all attempts by Member States to give full effect in national law to provisions of Directives or Regulations. They are not unique to the data protection context in general, or to Article 82 GDPR in particular, though the lesson of Collins is to be wary of such problems in this context. The outcome of Collins was a tragedy, but it might not be entirely straightforward to avoid repeating it. ${ }^{232}$ On the one hand, if Member States do not incorporate that Article, and it is ambiguous, then they could either be liable in damages to a plaintiff deprived of that Article's claim for compensation, or - worse - be faced with an infringement action by the EU Commission, or - worst of all - both. On the other hand, if they do incorporate that Article, but do so inaccurately or incompletely, then they could again be faced with such actions. Hence, some Member States could be damned if they do seek to incorporate Article 82 GDPR and get it wrong; others could damned if they do not seek to incorporate it and discover that they should have. It is a catch $^{233}$ that could have been avoided by more careful drafting of Article 82 GDPR. All in all, the best solution is the provision, in Heads 58 and 91, of a carefully drafted framework for an effective judicial remedy that contains an express claim for compensation modelled as much as possible on Articles 54 and 56 PCAJD and Articles 79 and 82 GDPR.

Similar considerations will apply in the context of any legislation incorporating Articles 21 and 22 pePR: to avoid the possibility of a Dillenkofer claim or an infringement action, it too should provide a framework for an effective judicial remedy that contains an express claim for compensation modelled as much as possible on those Articles.

The amendments to Heads 58 and 91, and the draft incorporating Article 22 pePR, suggested here, or something like them, would certainly ensure that Head 58 would be an accurate and complete implementation of Articles 54 and 56 PCJAD and that

\footnotetext{
${ }^{230}$ Provided, of course, that the conditions for State liability are satisfied; see ns 176-77.

${ }^{231}$ Pursuant to Article 258 TFEU; see ns 40 and 178.

${ }^{232}$ Karl Marx, The Eighteenth Brumaire of Louis Bonaparte (1852, International Publishers 1963) 1: 'Hegel remarks somewhere that all great world-historic facts and personages appear, so to speak, twice. He forgot to add: the first time as tragedy, the second time as farce.'

${ }^{233}$ Joseph Heller, Catch-22 (Simon \& Schuster 2011) 55 ('There was only one catch and that was Catch-22 ...').
} 
Head 91 would be an accurate and complete incorporation of Articles 79 and 82 GDPR.

\section{CONCLUSION}

In Romeo and Juliet, Juliet's sense of privacy is critical to the beginning of the balcony scene. ${ }^{234}$ Indeed, not only do contemporary notions of privacy drive crucial aspects of the plot of Romeo and Juliet, they are also central to Hamlet and Twelfth Night. ${ }^{235}$ We share Juliet's outrage when she thinks her privacy been invaded by Romeo. It is not anachronistic to think that Elizabethan audiences would have reacted in the same way, as it was in Shakespeare's time that the idea of privacy probably commenced the process of moving from a marginal notion to a desirable quality. ${ }^{236}$ Indeed, it is now a fundamental right, protected in many instruments, including Articles 7 and 8 FCR, and Article 16(1) TFEU, and Article 39 TEU, which are the legal basis upon which the General Data Protection Regulation has been adopted. It is founded upon a mutually reinforcing combination of public and private enforcement that blends public fines with private damages, to ensure, in particular, that those whose GDPR rights are infringed have effective judicial remedies pursuant to Article 47 CFR.

Article 82(1) GDPR provides for a claim for compensation that is to be incorporated into Irish law by Head 91 of the General Scheme of the Data Protection Bill 2017. The analogous Article 56 PCJAD is to be implemented into Irish law by Head 58 of the Scheme. Article 22 pePR is in terms similar to Article 82(1) GDPR; the enforcement of the pePR will be integrated with that of the GDPR, so Article 22 pePR will likely have to be incorporated in much the same way as Article 82 GDPR.

The claims for compensation in Heads 58 and 91 meet the obligation upon the State, pursuant to Article 19 TEU, to provide remedies sufficient to ensure effective legal protection in the field of data protection. Those Heads are important to ensure the effectiveness of the data protection regime in the GDPR, the PCJAD, and the Scheme, and to encourage its private enforcement. However, whilst Head 91 provides the framework for an effective judicial remedy, it does not expressly include a claim for compensation. Rather, it seems to assume that Article 82(1) GDPR

\footnotetext{
${ }^{234}$ Luminita Frentiu, What's in a Balcony Scene? A Study on Shakespeare's Romeo and Juliet and its Adaptations (Cambridge Scholars Publishing 2017).

${ }^{235}$ Ronald Huebert, Privacy in the Age of Shakespeare: Evolving Relationships in a Changing Environment (University of Toronto Press 2016) ch 1.

${ }^{236}$ Huebert, ibid; contrast Lawrence Friedman, Guarding Life's Dark Secrets: Legal and Social Controls over Reputation, Propriety, and Privacy (Stanford University Press 2007) (privacy is a modern invention); Oliver Diggelmann and Maria Nicole Cleis, 'How the Right to Privacy Became a Human Right' (2014) 14(3) Human Rights Law Review 441.
} 
provides that claim. That is not a safe assumption. The formulation of the claim for compensation in that Article (and following it, in Article 22 pePR) is far more ambiguous than it should have been, contingent upon further steps that are not provided in the GDPR. To ensure that plaintiffs have an effective remedy pursuant to Article 47 CFR, Member States will, pursuant to Article 19 TEU, have to provide the additional mechanism by which these further steps can be taken. Consequently, an express claim for compensation should be added to Head 91, to ensure that plaintiffs 'shall' have effective claims to compensation pursuant to Article 82(1) GDPR.

The contingency in Article 82(1) GDPR is clear when it is contrasted with compensation provisions in other Regulations, such as the Flight Compensation Regulation, and with other provisions of the GDPR. Moreover, it is a contingency found in five of the 24 official language texts of the GDPR, and that is five too many ambiguous versions. The CJEU has provided expansive interpretations of claims for compensation pursuant to various Regulations and Directives. In particular, in the context of the Flight Compensation Regulation in Sturgeon, the Court stressed that compensation provisions must be interpreted broadly; in the context of the original Equal Treatment Directive in Marshall, the Court emphasised that compensation must be full compensation; and, in the context of the original Package Holidays Directive in Leitner, the Court held that the claim for compensation covered nonmaterial damage such as distress. In a wide variety of contexts, in Commission $v$ Portugal, Stadt Graz, Dekker, and Draehmpaehl, the Court emphasised that national law cannot make compensation claims subject to unnecessary conditions. And in Draehmpaehl, the Court stressed that national law must guarantee real and effective judicial protection for compensation claims. So, if it is asked, the CJEU will interpret Article 82(1) GDPR teleologically and expansively, and resolve the ambiguities at its heart. But it should not come to this; it would be better to have this matter settled by legislation rather than leaving it to the vagaries of litigation. Consequently, an express claim for compensation should be added to Head 91 of the Scheme. Indeed, of the 12 Member States (other than Ireland) which have, so far, produced reports, Bills or Acts on GDPR incorporation, seven have provided for express claims to compensation.

Moreover, whilst Head 91 is an incomplete incorporation of Article 82(1) GDPR, Head 58 is an incomplete implementation of Article 56 PCJAD. Whereas Head 91 provides a framework for an effective judicial remedy but does not contain an express claim for damages, Head 58 does the exact reverse - it contains an express claim for damages but does not provide a framework for an effective judicial remedy. So, if an express claim for damages ought to be added to Head 91, a framework for an effective judicial remedy ought to be added to Head 58. In this way, the issues of compensation and remedies for infringement of the GDPR and the 
PCJAD will follow a common framework, and will be dealt with on a consistent basis in the Scheme.

In making these changes to Heads 58 and 91, four lessons can be learned from the current provisions - s 7 DPA 1988 implementing Article 23 DPD, and Regulation 16(2) PECR implementing Article 15(2) ePD - that will be superseded when the Scheme comes into effect. First, like the straightforward Regulation 16(2) PECR and unlike the baleful s 7 DPA 1988, Heads 58 and 91 should not seek to reinvent the drafting wheel. Instead, they should simply use as much of the language of Article 56 PCJAD and 82 GDPR as possible. This will avoid outcomes like Collins, without having to undergo the analytical gymnastics of Vidal-Hall. Second, because of the role of the revamped Data Protection Commission in public regulation and enforcement, private enforcement claims for compensation or damages should be clearly a matter for the courts. Third, the damages claims in Heads 58 and 91 should be expressly characterised as tort claims, so that tort law can uncontroversially provide answers to many fundamental issues relating to such claims. Fourth, Heads 58 and 91 should be as complete as possible in their implementation or incorporation of Article 56 PCJAD and Article 82 GDPR. Similar lessons should be applied to the incorporation of Article 22 pePR. Amendments to Heads 58 and 91, and possible provisions to incorporate Article 22 pePR, are therefore suggested in Appendix II.

After the misinterpretation of s 7 DPA 1988 in Collins, the State must have potentially been open either to a Dillenkofer claim for damages from someone who suffered distress as a result of a breach of the DPA 1988, or to an infringement action by the EU Commission on the grounds that $\mathrm{s} 7$ is an inaccurate or incomplete implementation of Article 23 DPD. Similar actions potentially confront States which either fail to incorporate Article 82 GDPR and then find that they ought to have, or seek to incorporate it but do so inaccurately or incompletely. Faced with this dilemma, the least worst option is to provide for an express claim to compensation in national incorporations of the GDPR. In particular, the Irish incorporation ought to be drafted along the lines suggested here and set out in Appendix II.

Claims for compensation are an important part of the enforcement architecture of the GDPR, of its associated PCJAD, and of the Scheme. Private enforcement will help to discourage infringements of the rights of data subjects; it will make a significant contribution to the protection of privacy and data protection rights in the European Union; and it will help to ensure that the great promise of the GDPR is fully realised. 


\section{Appendix I}

\section{Some Relevant Provisions of EU Law}

1. Treaty on European Union ${ }^{237}$

Article 19

1. ... Member States shall provide remedies sufficient to ensure effective legal protection in the fields covered by Union law.

\section{Article 39}

In accordance with Article 16 of the Treaty on the Functioning of the European Union and by way of derogation from paragraph 2 thereof, the Council shall adopt a decision laying down the rules relating to the protection of individuals with regard to the processing of personal data by the Member States when carrying out activities which fall within the scope of this Chapter, and the rules relating to the free movement of such data. Compliance with these rules shall be subject to the control of independent authorities.

\section{Treaty on the Functioning of the European Union ${ }^{238}$}

Article 16

(ex Article 286 TEC)

1. Everyone has the right to the protection of personal data concerning them.

2. The European Parliament and the Council, acting in accordance with the ordinary legislative procedure, shall lay down the rules relating to the protection of individuals with regard to the processing of personal data by Union institutions, bodies, offices and agencies, and by the Member States when carrying out activities which fall within the scope of Union law, and the rules relating to the free movement of such data. Compliance with these rules shall be subject to the control of independent authorities.

The rules adopted on the basis of this Article shall be without prejudice to the specific rules laid down in Article 39 of the Treaty on European Union.

\section{Charter of Fundamental Rights ${ }^{239}$}

\section{TITLE II \\ FREEDOMS}

Article 7

\section{Respect for private and family life}

Everyone has the right to respect for his or her private and family life, home and communications.

Article 8

\section{Protection of personal data}

1. Everyone has the right to the protection of personal data concerning him or her.

2. Such data must be processed fairly for specified purposes and on the basis of the consent of the person concerned or some other legitimate basis laid down by law. Everyone has the right of access to data which has been collected concerning him or her, and the right to have it rectified.

\footnotetext{
${ }^{237}$ Treaty on the European Union (2012 OJ C 326).

${ }^{238}$ Treaty on the Functioning of the European Union (2012 OJ C 326).

${ }^{239}$ Charter Fundamental Rights of the European Union (2012 OJ C 326/2).
} 
3. Compliance with these rules shall be subject to control by an independent authority.

TITLE VI

JUSTICE

Article 47

Right to an effective remedy and to a fair trial

Everyone whose rights and freedoms guaranteed by the law of the Union are violated has the right to an effective remedy before a tribunal in compliance with the conditions laid down in this Article.

Everyone is entitled to a fair and public hearing within a reasonable time by an independent and impartial tribunal previously established by law. Everyone shall have the possibility of being advised, defended and represented.

Legal aid shall be made available to those who lack sufficient resources in so far as such aid is necessary to ensure effective access to justice.

\section{General Data Protection Regulation ${ }^{240}$}

THE EUROPEAN PARLIAMENT AND THE COUNCIL OF THE EUROPEAN UNION,

Having regard to the Treaty on the Functioning of the European Union, and in particular Article 16 thereof, ...

Whereas:

\section{Recital 1}

The protection of natural persons in relation to the processing of personal data is a fundamental right. Article 8(1) of the Charter of Fundamental Rights of the European Union (the 'Charter') and Article 16(1) of the Treaty on the Functioning of the European Union (TFEU) provide that everyone has the right to the protection of personal data concerning him or her.

\section{Recital 8}

Where this Regulation provides for specifications or restrictions of its rules by Member State law, Member States may, as far as necessary for coherence and for making the national provisions comprehensible to the persons to whom they apply, incorporate elements of this Regulation into their national law.

\section{Recital 146}

The controller or processor should compensate any damage which a person may suffer as a result of processing that infringes this Regulation. The controller or processor should be exempt from liability if it proves that it is not in any way responsible for the damage. The concept of damage should be broadly interpreted in the light of the case law of the Court of Justice in a manner which fully reflects the objectives of this Regulation. This is without prejudice to any claims for damage deriving from the violation of other rules in Union or Member State law. Processing that infringes this Regulation also includes processing that infringes delegated and implementing acts adopted in accordance with this Regulation and Member State law specifying rules of this Regulation. Data subjects should receive full and effective compensation for the damage they have suffered. Where controllers or processors are involved in the same processing, each controller or processor should be held liable for the entire damage. However, where they are joined to the same judicial proceedings, in

\footnotetext{
${ }^{240}$ Regulation 2016/679 of the European Parliament and of the Council of 27 April 2016 on the protection of natural persons with regard to the processing of personal data and on the free movement of such data, and repealing Directive 95/46/EC (2016 OJ L 119).
} 
accordance with Member State law, compensation may be apportioned according to the responsibility of each controller or processor for the damage caused by the processing, provided that full and effective compensation of the data subject who suffered the damage is ensured. Any controller or processor which has paid full compensation may subsequently institute recourse proceedings against other controllers or processors involved in the same processing.

...

HAVE ADOPTED THIS REGULATION:

\section{Article 79}

Right to an effective judicial remedy against a controller or processor

1. Without prejudice to any available administrative or non-judicial remedy, including the right to lodge a complaint with a supervisory authority pursuant to Article 77, each data subject shall have the right to an effective judicial remedy where he or she considers that his or her rights under this Regulation have been infringed as a result of the processing of his or her personal data in non-compliance with this Regulation.

2. Proceedings against a controller or a processor shall be brought before the courts of the Member State where the controller or processor has an establishment. Alternatively, such proceedings may be brought before the courts of the Member State where the data subject has his or her habitual residence, unless the controller or processor is a public authority of a Member State acting in the exercise of its public powers.

\section{Article 82}

\section{Right to compensation and liability}

1. Any person who has suffered material or non-material damage as a result of an infringement of this Regulation shall have the right to receive compensation from the controller or processor for the damage suffered.

2. Any controller involved in processing shall be liable for the damage caused by processing which infringes this Regulation. A processor shall be liable for the damage caused by processing only where it has not complied with obligations of this Regulation specifically directed to processors or where it has acted outside or contrary to lawful instructions of the controller.

3. A controller or processor shall be exempt from liability under paragraph 2 if it proves that it is not in any way responsible for the event giving rise to the damage.

4. Where more than one controller or processor, or both a controller and a processor, are involved in the same processing and where they are, under paragraphs 2 and 3 , responsible for any damage caused by processing, each controller or processor shall be held liable for the entire damage in order to ensure effective compensation of the data subject.

5. Where a controller or processor has, in accordance with paragraph 4, paid full compensation for the damage suffered, that controller or processor shall be entitled to claim back from the other controllers or processors involved in the same processing that part of the compensation corresponding to their part of responsibility for the damage, in accordance with the conditions set out in paragraph 2.

6. Court proceedings for exercising the right to receive compensation shall be brought before the courts competent under the law of the Member State referred to in Article 79(2). 


\section{The Police and Criminal Justice Authorities Directive ${ }^{241}$}

\section{Recital 88}

Any damage which a person may suffer as a result of processing that infringes the provisions adopted pursuant to this Directive should be compensated by the controller or any other authority competent under Member State law. The concept of damage should be broadly interpreted in the light of the case law of the Court of Justice in a manner which fully reflects the objectives of this Directive. This is without prejudice to any claims for damage deriving from the violation of other rules in Union or Member State law. When reference is made to processing that is unlawful or that infringes the provisions adopted pursuant to this Directive it also covers processing that infringes implementing acts adopted pursuant to this Directive. Data subjects should receive full and effective compensation for the damage that they have suffered.

\section{Article 54}

\section{Right to an effective judicial remedy against a controller or processor}

Without prejudice to any available administrative or non-judicial remedy, including the right to lodge a complaint with a supervisory authority pursuant to Article 52, Member States shall provide for the right of a data subject to an effective judicial remedy where he or she considers that his or her rights laid down in provisions adopted pursuant to this Directive have been infringed as a result of the processing of his or her personal data in noncompliance with those provisions.

\section{Article 56}

\section{Right to compensation}

Member States shall provide for any person who has suffered material or non-material damage as a result of an unlawful processing operation or of any act infringing national provisions adopted pursuant to this Directive to have the right to receive compensation for the damage suffered from the controller or any other authority competent under Member State law.

\section{The proposed ePrivacy Regulation ${ }^{242}$}

\section{Article 21}

\section{Remedies}

1. Without prejudice to any other administrative or judicial remedy, every end-user of electronic communications services shall have the same remedies provided for in Articles 77, 78, and 79 of Regulation (EU) 2016/679.

2. Any natural or legal person other than end-users adversely affected by infringements of this Regulation and having a legitimate interest in the cessation or prohibition of alleged infringements, including a provider of electronic communications services protecting its legitimate business interests, shall have a right to bring legal proceedings in respect of such infringements.

\footnotetext{
${ }^{241}$ Directive (EU) 2016/680 of the European Parliament and of the Council of 27 April 2016 on the protection of natural persons with regard to the processing of personal data by competent authorities for the purposes of the prevention, investigation, detection or prosecution of criminal offences or the execution of criminal penalties, and on the free movement of such data, and repealing Council Framework Decision 2008/977/JHA (2016 OJ L 116).

${ }^{242}$ Proposal 2017/0003 of 10 January 2017 for a Regulation of the European Parliament and of the Council concerning the respect for private life and the protection of personal data in electronic communications and repealing Directive 2002/58/EC (COM(2017) 10 final - 2017/03 (COD)).
} 


\section{Article 22}

\section{Right to compensation and liability}

Any end-user of electronic communications services who has suffered material or nonmaterial damage as a result of an infringement of this Regulation shall have the right to receive compensation from the infringer for the damage suffered, unless the infringer proves that it is not in any way responsible for the event giving rise to the damage in accordance with Article 82 of Regulation (EU) 2016/679.

\section{The Data Protection Directive ${ }^{243}$}

\section{Article 22}

\section{Remedies}

Without prejudice to any administrative remedy for which provision may be made, inter alia before the supervisory authority referred to in Article 28, prior to referral to the judicial authority, Member States shall provide for the right of every person to a judicial remedy for any breach of the rights guaranteed him by the national law applicable to the processing in question.

\section{Article 23}

\section{Liability}

1. Member States shall provide that any person who has suffered damage as a result of an unlawful processing operation or of any act incompatible with the national provisions adopted pursuant to this Directive is entitled to receive compensation from the controller for the damage suffered.

2. The controller may be exempted from this liability, in whole or in part, if he proves that he is not responsible for the event giving rise to the damage.

\section{The ePrivacy Directive ${ }^{244}$}

Article 15

\section{Application of certain provisions of Directive 95/46/EC}

1.

2. The provisions of Chapter III on judicial remedies, liability and sanctions of Directive 95/46/EC shall apply with regard to national provisions adopted pursuant to this Directive and with regard to the individual rights derived from this Directive.

3.

\footnotetext{
${ }^{243}$ Directive 95/46/EC of the European Parliament and of the Council of 24 October 1995 on the protection of individuals with regard to the processing of personal data and on the free movement of such data (1995 OJ L 281).

${ }^{244}$ Directive 2002/58/EC of the European Parliament and of the Council of 12 July 2002 concerning the processing of personal data and the protection of privacy in the electronic communications sector (2002 OJ L 201); as amended by Directive 2006/24/EC of the European Parliament and of the Council of 15 March 2006 on the retention of data generated or processed in connection with the provision of publicly available electronic communications services or of public communications networks and amending Directive 2002/58/EC (2006 OJ L 105); and as further amended by Directive 2009/136/EC of the European Parliament and of the Council of 25 November 2009 amending Directive 2002/22/EC on universal service and users' rights relating to electronic communications networks and services, Directive 2002/58/EC concerning the processing of personal data and the protection of privacy in the electronic communications sector and Regulation (EC) No 2006/2004 on cooperation between national authorities responsible for the enforcement of consumer protection laws (2009 OJ L 337).
} 


\section{Appendix II}

\section{Some Provisions of, and Suggested Amendments to, the General Scheme of the Data Protection Bill $2017^{245}$}

\section{Heads $\mathbf{5 8}$ and 91 of the Scheme as published}

Head 58 - Right to compensation

A person who suffers material or non-material damage by reason of an infringement of this Part shall have the right to receive compensation from the competent authority or processor for damage or distress suffered.

Head 91 - Judicial remedy

(1) Where a data subject considers that his or her rights under the Regulation or this Act have been infringed as a result of processing of his or her personal data, such infringement shall be actionable at the suit of the data subject ('data protection action').

(2) The Circuit Court shall, concurrently with the High Court, have jurisdiction to hear and determine proceedings under this Head.

(3) In a data protection action under this Head, the Circuit Court shall, without prejudice to its powers to award compensation in respect of material or non-material damage, have the power to grant relief by means of injunction or declaratory orders.

(4) For the purpose of commencing a data protection action, the data subject shall, in particular, specify-

(a) particulars of the acts of the controller or processor constituting the alleged infringement, and

(b) any material or non-material damage alleged to have been occasioned by the infringement.

(5) The jurisdiction conferred on the Circuit Court by this Head may be exercised by the judge of the circuit in which-

(a) the controller or processor has an establishment, or

(b) the data subject has his or her habitual residence except where the alleged controller or processor is a public authority of the State acting in the exercise of its public powers.

\section{Suggested amendments to Heads 58 and 91}

Suggested additions appear thus; suggested deletions appear thus

Head 58 - Right to Judicial remedy and damages

(1) Where a person considers that his or her rights have been infringed as a result of an unlawful processing operation or other act infringing this Part, then such unlawful processing or other infringement is actionable at the suit of the person concerned ('infringement action').

(2) In an infringement action under this Head, a A person who has suffered suffers material or non-material damage as a result of by reason of an infringement of this Part shall have the right to receive compensation is entitled to damages from the competent authority or processor for the damage distress suffered.

\footnotetext{
${ }^{245}$ The draft General Scheme of a Data Protection Bill 2017 <http://www.justice.ie/en/JELR/Pages/PR17000155>.
} 
(3) The Circuit Court, concurrently with the High Court, has jurisdiction to hear and determine proceedings in infringement actions under this Head.

(4) In an infringement action under this Head, the Circuit Court, without prejudice to its powers to award damages pursuant to sub-Head (2), also has the power to grant relief by means of injunction or declaratory orders.

(5) For the purpose of commencing an infringement action, the plaintiff must, in particular, specify-

(a) particulars of the acts of the competent authority or processor constituting the alleged unlawful processing or other infringement, and

(b) any material or non-material damage alleged to have been occasioned by the alleged unlawful processing or other infringement.

(6) The jurisdiction conferred on the Circuit Court by this Head may be exercised by the judge of the circuit in which-

(a) the competent authority or processor has an establishment, or

(b) the data subject has his or her habitual residence except where the competent authority or processor is a public authority of the State acting in the exercise of its public powers.

(7) For the purposes of every enactment and rule of law, an infringement action under this Head is an action founded on tort.

(8) In an infringement action under this Head, it is a defence for a competent authority or processor to show that it is not in any way responsible for the event giving rise to the alleged damage.

Head 91 - Judicial remedy and damages

(1) Where a data subject considers that his or her rights under the Regulation or this Act have been infringed as a result of processing of his or her personal data, such infringement shall be is actionable at the suit of the data subject ('data protection action').

(2) In a data protection action under this Head, a data subject who has suffered material or non-material damage as a result of an infringement of the Regulation or this Act is entitled to damages from the controller or processor for the damage suffered.

(3)(2) The Circuit Court shall, concurrently with the High Court, have has jurisdiction to hear and determine proceedings in data protection actions under this Head.

(4)(3) In a data protection action under this Head, the Circuit Court shall, without prejudice to its powers to award damages pursuant to sub-Head (2), also compenstion in of materialor non-materialdamage, have has the power to grant relief by means of injunction or declaratory orders.

(5)(4) For the purpose of commencing a data protection action, the data subject shall must, in particular, specify-

(a) particulars of the acts of the controller or processor constituting the alleged infringement, and

(b) any material or non-material damage alleged to have been occasioned by the alleged infringement.

(6)(5) The jurisdiction conferred on the Circuit Court by this Head may be exercised by the judge of the circuit in which-

(a) the controller or processor has an establishment, or 
(b) the data subject has his or her habitual residence except where the controller or processor is a public authority of the State acting in the exercise of its public powers.

(7) For the purposes of every enactment and rule of law, an infringement action under this Head is an action founded on tort.

(8) (a) Without prejudice to its liability as a controller, any controller involved in processing is also liable in a data protection action under this Head for the damage caused by processing which infringes the Regulation or this Act.

(b) A processor is liable in a data protection action under this Head for the damage caused by processing only where it has not complied with obligations of the Regulation or this Act specifically directed to processors or where it has acted outside or contrary to lawful instructions of the controller.

(c) In a data protection action under this Head, it is a defence for a controller or processor to show that it is not in any way responsible for the event giving rise to the alleged damage.

\section{Heads $\mathbf{5 8}$ and $\mathbf{9 1}$ after suggested amendment}

Head 58 - Judicial remedy and damages

(1) Where a person considers that his or her rights have been infringed as a result of an unlawful processing operation or other act infringing this Part, then such unlawful processing or other infringement is actionable at the suit of the person concerned ('infringement action').

(2) In an infringement action under this Head, a person who has suffered material or non-material damage as a result of an infringement of this Part is entitled to damages from the competent authority or processor for the damage suffered.

(3) The Circuit Court, concurrently with the High Court, has jurisdiction to hear and determine proceedings in infringement actions under this Head.

(4) In an infringement action under this Head, the Circuit Court, without prejudice to its powers to award damages pursuant to sub-Head (2), also has the power to grant relief by means of injunction or declaratory orders.

(5) For the purpose of commencing an infringement action, the plaintiff must, in particular, specify-

(a) particulars of the acts of the competent authority or processor constituting the alleged unlawful processing or other infringement, and

(b) any material or non-material damage alleged to have been occasioned by the alleged unlawful processing or other infringement.

(6) The jurisdiction conferred on the Circuit Court by this Head may be exercised by the judge of the circuit in which-

(a) the competent authority or processor has an establishment, or

(b) the data subject has his or her habitual residence except where the competent authority or processor is a public authority of the State acting in the exercise of its public powers.

(7) For the purposes of every enactment and rule of law, an infringement action under this Head is an action founded on tort.

(8) In an infringement action under this Head, it is a defence for a competent authority or processor to show that it is not in any way responsible for the event giving rise to the alleged damage. 
Head 91 - Judicial remedy and damages

(1) Where a data subject considers that his or her rights under the Regulation or this Act have been infringed as a result of processing of his or her personal data, such infringement is actionable at the suit of the data subject ('data protection action').

(2) In a data protection action under this Head, a data subject who has suffered material or non-material damage as a result of an infringement of the Regulation or this Act is entitled to damages from the controller or processor for the damage suffered.

(3) The Circuit Court, concurrently with the High Court, has jurisdiction to hear and determine proceedings in data protection actions under this Head.

(4) In a data protection action under this Head, the Circuit Court, without prejudice to its powers to award damages pursuant to sub-Head (2), also has the power to grant relief by means of injunction or declaratory orders.

(5) For the purpose of commencing a data protection action, the data subject must, in particular, specify-

(a) particulars of the acts of the controller or processor constituting the alleged infringement, and

(b) any material or non-material damage alleged to have been occasioned by the alleged infringement.

(6) The jurisdiction conferred on the Circuit Court by this Head may be exercised by the judge of the circuit in which-

(a) the controller or processor has an establishment, or

(b) the data subject has his or her habitual residence except where the controller or processor is a public authority of the State acting in the exercise of its public powers.

(7) For the purposes of every enactment and rule of law, an infringement action under this Head is an action founded on tort.

(8) (a) Without prejudice to its liability as a controller, any controller involved in processing is also liable in a data protection action under this Head for the damage caused by processing which infringes the Regulation or this Act.

(b) A processor is liable in a data protection action under this Head for the damage caused by processing only where it has not complied with obligations of the Regulation or this Act specifically directed to processors or where it has acted outside or contrary to lawful instructions of the controller.

(c) In a data protection action under this Head, it is a defence for a controller or processor to show that it is not in any way responsible for the event giving rise to the alleged damage.

\section{Proposal for a provision to incorporate Article 22 pePR}

Head XX - Judicial remedy and damages

(1) Where an end-user of electronic communications services considers that his or her rights under the Regulation or this Act have been infringed, such infringement is actionable at the suit of the data subject ('e-privacy action').

(2) In an e-privacy action under this Head, a data subject who has suffered material or non-material damage as a result of an infringement of the Regulation or this Act is entitled to damages from the controller or processor for the damage suffered.

(3) The Circuit Court, concurrently with the High Court, has jurisdiction to hear and determine proceedings in e-privacy actions under this Head. 
(4) In an e-privacy action under this Head, the Circuit Court, without prejudice to its powers to award damages pursuant to sub-Head (2), also has the power to grant relief by means of injunction or declaratory orders.

(5) For the purpose of commencing an e-privacy action, the data subject must, in particular, specify-

(a) particulars of the acts of the controller or processor constituting the alleged infringement, and

(b) any material or non-material damage alleged to have been occasioned by the alleged infringement.

(6) The jurisdiction conferred on the Circuit Court by this Head may be exercised by the judge of the circuit in which-

(a) the alleged controller or processor has an establishment, or

(b) the data subject has his or her habitual residence except where the alleged controller or processor is a public authority of the State acting in the exercise of its public powers.

(7) For the purposes of every enactment and rule of law, an e-privacy action under this Head is an action founded on tort.

(8) (a) A processor is liable in an e-privacy action under this Head for the damage caused by processing only where it has not complied with obligations of the Regulation or this Act specifically directed to processors.

(b) In an e-privacy action under this Head, it is a defence for a processor to show that it is not in any way responsible for the event giving rise to the alleged damage. 


\section{Appendix III \\ Formulations of the Claim for Compensation in Article 82(1) GDPR in the EU's 24 Official Languages ${ }^{246}$; and Links to Acts or Bills in Member States incorporating the GDPR ${ }^{247}$}
BG
Bulgarian: има право да получи обезщетение = ima pravo da poluchi obezshtetenie $=$ is entitled to compensation
CS Czech: má právo obdržet ... náhradu = has the right to receive ... compensation
DA Danish: har ret til erstatning $=$ has the right to compensation ${ }^{248}$
DE German: hat Anspruch auf Schadenersatz = is entitled to compensation ${ }^{249}$
ES Spanish: tendrá derecho a recibir ... una indemnización = shall have the right to receive ... compensation ${ }^{250}$
ET Estonian: on õigus saada ... hüvitist $=$ is entitled to ... compensation ${ }^{251}$

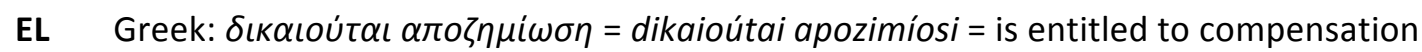

\footnotetext{
${ }^{246}$ The official and working languages of the EU institutions are set out in Article 1 of EEC Council Regulation No 1 of 15 April 1958 determining the language to be used by the European Economic Community (1958 OJ 17), as amended, most recently, by Article 18 of the Annex to Council Regulation (EU) No 517/2013 of 13 May 2013 adapting certain regulations and decisions in the fields of free movement of goods, freedom of movement for persons, company law, competition policy, agriculture, food safety, veterinary and phytosanitary policy, transport policy, energy, taxation, statistics, trans-European networks, judiciary and fundamental rights, justice, freedom and security, environment, customs union, external relations, foreign, security and defence policy and institutions, by reason of the accession of the Republic of Croatia (2013 OJ L 158), adding Croatian to the list of official and working languages.

${ }^{247}$ The entries are alphabetical according to the EU's two-letter language codes; see, eg, Annex I of Regulation (EC) No 1059/2003 of the European Parliament and of the Council of 26 May 2003 on the establishment of a common classification of territorial units for statistics (NUTS) (2003 OJ L 154), as amended, most recently, by Article 10(5) of the Annex to Council Regulation (EU) No 517/2013 (2013 OJ L 158), adding HR (for Hrvatski = Croatian) to the list of two-letter language codes.

See also Europa Interinstitutional Style Guide, §§7.1.1 and 7.2.1

<http://publications.europa.eu/code/en/en-370100.htm> and <http://publications.europa.eu/code/en/en370200.htm>.

${ }^{248}$ A comprehensive Report on the Data Protection Regulation prepared for the Ministry of Justice contains a thorough analysis of Article 82 GDPR and corresponding Danish law, but does not recommend a compensation claim (989-918)

<http://justitsministeriet.dk/sites/default/files/media/Pressemeddelelser/pdf/2017/betaenkning_1565_del_i_bi nd_2.pdf>.

${ }^{249}$ In Austria, legislation provides a compensation claim; see $\$ 29$ of Bundesgesetz, mit dem das Datenschutzgesetz 2000 geändert wird (DatenschutzAnpassungsgesetz 2018)

<https://www.ris.bka.gv.at/eli/bgbl/l/2017/120/20170731>.

In Germany, legislation does not provide a compensation claim; see Gesetz zur Anpassung des Datenschutzrechts an die Verordnung (EU) 2016/679 und zur Umsetzung der Richtlinie (EU) 2016/680 (Datenschutz-Anpassungs- und -Umsetzungsgesetz EU - DSAnpUG-EU); (Gesetz vom 30 Juni 2017; Bundesgesetzblatt Teil I, 2097)

<https://www.bgbl.de/xaver/bgbl/start.xav?startbk=Bundesanzeiger_BGBl\#_bgbl_\%2F\%2F*\%5B\%40attr_id\%3 D\%27bgbl117s2097.pdf\%27\%5D_1501246642435>.

The official English translation is: Act to Adapt Data Protection Law to Regulation (EU) 2016/679 and to Implement Directive (EU) 2016/680 (DSAnpUG-EU)

<http://www.bmi.bund.de/SharedDocs/Downloads/EN/Gesetzestexte/datenschutzanpassungsumsetzungsgesetz .pdf?_blob=publicationFile>.

${ }^{250} \mathrm{~A}$ draft Bill provides a compensation claim; see Article 32(2) of Anteproyecto de Ley Orgánica de Protección de Datos de Carácter Personal <http://www.mjusticia.gob.es/cs/Satellite/Portal/1292428461386>.

${ }^{251}$ There is no recommendation for a compensation claim in a report on a new legal framework for the protection of personal data prepared by the Ministry of Justice <http://www.aki.ee/sites/www.aki.ee/files/elfinder/article_files/andmekaitse_kontseptsioon_11.04.2017.pdf>.
} 
EN English: shall have the right to receive compensation = shall have the right to receive compensation ${ }^{252}$

FI Finnish: hänellä on oikeus saada ... korvaus = has the right to receive ... compensation ${ }^{253}$

FR French: a le droit d'obtenir... réparation $=$ has the right to obtain ... compensation ${ }^{254}$

GA Irish: beidh sé $i$ dteideal cúiteamh a fháil = shall be entitled to compensation ${ }^{255}$

HR Croatian: ima pravo na naknadu = has the right to compensation

HU Hungarian: kártérítésre jogosult $=$ is entitled to compensation ${ }^{256}$

IT Italian: ha il diritto di ottenere il risarcimento = has the right to obtain compensation

LT Lithuanian: turi teise ... gauti kompensacijq $=$ has the right ... to receive compensation ${ }^{257}$

LV Latvian: ir tiesïbas ... sanemt kompensāciju = has the right ... to receive compensation ${ }^{258}$

MT Maltese: ghandu jkollha d-dritt li tircievi kumpens = shall have the right to receive compensation

NL Dutch: heeft het recht ... schadevergoeding te ontvangen = has the right ... to receive compensation ${ }^{259}$

${ }^{252}$ For Ireland, see ns 22 and 255. In the United Kingdom, clause 159 of the Data Protection Bill 2017 provides a compensation claim, and it refers to Article 82 GDPR <https://publications.parliament.uk/pa/bills/lbill/20172019/0066/lbill_2017-20190066_en_1.htm>.

${ }^{253}$ EU:n yleisen tietosuoja-asetuksen täytäntöönpanotyöryhmän (TATTI) mietintö, the Report of the Working Group appointed by the Finnish Ministry of Justice (62), considers that Article 82 GDPR does not need national incorporation <http://julkaisut.valtioneuvosto.fi/handle/10024/80098>.

${ }^{254}$ In Belgium, there is no compensation claim in the draft Bill, Projet de Loi portant création de l'Autorité de protection des données <http://www.dekamer.be/flwb/pdf/54/2648/54K2648001.pdf>.

In France, legislation does not provide a compensation claim; see LOI n²016-1321 du 7 octobre

2016 pour une République numérique

<https://www.legifrance.gouv.fr/affichTexte.do?cidTexte=JORFTEXT000033202746\&categorieLien=id>.

However, this may not be the end of the French story; the Commission Nationale de l'Informatique et des

Libertés suggests that further legislation is required; see CNIL Rapport d'activité 2016, 23

<https://www.cnil.fr/sites/default/files/atoms/files/cnil-37e_rapport_annuel_2016.pdf>.

In Luxembourg, neither of two Bills on GDPR incorporation provides for a compensation claim;

<http://www.chd.lu/wps/portal/public/Accueil/TravailALaChambre/Recherche/RoleDesAffaires?action=doDocpa Details\&id $=7049>$ and

<http://www.chd.lu/wps/portal/public/Accueil/TravailALaChambre/Recherche/RoleDesAffaires?action=doDocpa Details\&id=7184>.

${ }^{255}$ The Irish government published a draft General Scheme of a Data Protection Bill 2017 <http://www.justice.ie/en/JELR/Pages/PR17000155>.

${ }^{256}$ A draft Bill provides a compensation claim; see Article 9 of Előterjesztés az információs önrendelkezési jogról és az információszabadságról szóló 2011. évi CXII. törvény jogharmonizációs célú módosításáról, inserting a new Article 24 into existing legislation; a zip folder containing the Bill may be downloaded via $<$ http://www.kormany.hu/hu/dok?page=2\&source=5\&type=302\#! DocumentBrowse $>$.

${ }^{257}$ There is no compensation claim in the draft Bill, Projektas Asmens Duomenu Teisinès Apsaugos lstatymo NR. I-1374 Pakeitimo lıstatymas <https://eseimas.Irs.It/portal/legalAct/lt/TAP/6a4d604051d111e78869ae36ddd5784f>.

${ }^{258}$ There is no compensation claim in the draft Bill, Likumprojekts - Personas datu apstrādes likums $<$ https://www.tm.gov.lv/lv/cits/pazinojums-par-lidzdalibas-iespejam-likumprojekta-personas-datu-apstradeslikums-izstrades-procesa-l>.

${ }^{259}$ A draft Bill provides a compensation claim; see Article 36 of Regels ter uitvoering van Verordening (EU) 2016/679 van het Europees Parlement en de Raad van 27 april 2016 betreffende de bescherming van natuurlijke personen in verband met de verwerking van persoonsgegevens en betreffende het vrije verkeer van die gegevens en tot intrekking van Richtlijn 95/46/EG (algemene verordening gegevensbescherming) (PbEU 2016, L 119) (Uitvoeringswet Algemene verordening gegevensbescherming) <https://www.internetconsultatie.nl/uitvoeringswetavg/details>. 
PL Polish: ma prawo uzyskać ... odszkodowanie = has the right to obtain ... compensation ${ }^{260}$

PT Portuguese: tem direito a receber uma indemnização = has the right to receive compensation

RO Romanian: are dreptul să obțină despăgubiri = has the right to obtain compensation ${ }^{261}$

SK Slovak: má právo na náhradu = has the right to compensation ${ }^{262}$

SL Slovenian: ima pravico ... dobi odškodnino = has the right ... to receive compensation

SV Swedish: ska ha rätt till ersättning = shall have the right to compensation ${ }^{263}$

EEA Since the GDPR has EEA relevance, its incorporation into domestic law in EEA States may also be relevant:

Iceland: skal eiga rétt á skađabótum = shall be entitled to compensation ${ }^{264}$

Liechtenstein: no information

Norway: skal ha rett til å motta erstatning = shall be entitled to receive compensation ${ }^{265}$

\footnotetext{
${ }^{260}$ A draft Bill provides a compensation claim; see Articles 78 and 79 of of Ustawa o ochronie danych osobowych <https://www.gov.pl/documents/31305/0/Ustawa+o+ochronie+danych+osobowych+-+projekt++13.09.2017.pdf/cf80336f-823c-6803-a8c1-ff30a2249e84>.

${ }^{261}$ A draft Bill provides a compensation claim; see Article 14.11(3) of Lege pentru modificarea şi completarea Legii nr. 102/2005 privind înfiinţarea, organizarea şi funcţionarea Autorităţii Naţionale de Supraveghere a Prelucrării Datelor cu Caracter Personal, precum și pentru abrogarea Legii nr. 677/2001 pentru protecţia persoanelor cu privire la prelucrarea datelor cu caracter personal şi libera circulaţie a acestor date <http://81.181.207.101/frontend/documente_transparenta/72_1504614894_proiect\%20Lege.pdf>. ${ }^{262}$ A draft Bill provides a compensation claim; see $\$ 39$ of Návrh Zákon o ochrane osobných údajov a o zmene a doplnení niektorých zákonov <https://www.slov-lex.sk/legislativne-procesy/SK/LP/2017/453>.

${ }^{263}$ A draft Bill provides a compensation claim; see Chapter $8 \S 1$ of the draft Bill proposed in Ny dataskyddslag Kompletterande bestämmelser till EU:s dataskyddsförordning <http://www.regeringen.se/49a184/contentassets/e98119b4c08d4d60a0a2d0878990d5ec/ny-dataskyddslagsou-201739>.

${ }^{264}$ The Icelandic translation of the GDPR is available at $<$ https://www.personuvernd.is/nypersonuverndarloggjof-2018/drog-ad-thydingu-gdpr/>. Legislation is expected in Spring 2018; see $<$ https://www.stjornarradid.is/verkefni/personurettur/personuvernd/ny-personuverndarloggjof-2018/>. ${ }^{265}$ The Norwegian translation of the GDPR is available at <https://www.regjeringen.no/contentassets/c907cd2776264a6486b8dd3ee00a4e3d/uoffisiell-norskoversettelse-av-personvernforordningen.pdf $>$. There is no compensation claim in the draft Bill <https://www.regjeringen.no/contentassets/c907cd2776264a6486b8dd3ee00a4e3d/horingsnotat--nypersonopplysningslov--gjennomforing-av-personvernforordningen-i-norsk-rett.pdf>.

Note Information about incorporations will be updated at <http://www.cearta.ie/2017/07/what-is-the-current-status-of-gdpr-incorporation-in-the-eus-28-memberstates/>.
} 